\title{
The army and the spread of Roman citizenship
}

\section{MYLES LAVAN}

This paper draws recent advances in our knowledge (much of it owed to the proliferation of military diplomas) and a new analytical method to quantify the number of soldiers and their children who received Roman citizenship between 14 and 212 C.E. Although significant uncertainties remain, these can be quantified and turn out to be small relative to the overall scale of enfranchisement. The paper begins by reviewing what is known about grants of citizenship to soldiers, with particular attention to the remaining uncertainties, before presenting a quantitative model of the phenomenon. The total number of beneficiaries was somewhere in the region 0.9-1.6 million - significantly lower than previous estimates have suggested. It also emerges that the rate of enfranchisement varied substantially over time, in line with significant changes in manpower, length of service (and hence the number of recruits and discharged veterans) and in the rate of family formation among soldiers.

\section{KEYWORDS}

Roman army; Roman citizenship; Demography; auxilia; uncertainty; quantification

This is the author-final version of an article forthcoming in Journal of Roman Studies 109 (2019) (https://www.cambridge.org/core/journals/journal-of-roman-studies). (C copyright holder.

* I am grateful to the Leverhulme Trust and Arts and Humanities Research Council for Research Fellowships that funded this research. This article is supported by supplementary online appendices at <URL to be added $>$.

Service in the Roman army is the best attested of the routes by which provincials acquired Roman citizenship in the imperial period. The process is documented by the rapidly growing corpus of military diplomas, which now number more than 1,200. Yet few scholars have ventured even a rough estimate of the scale of the phenomenon. The handful of exceptions all envisage that the beneficiaries numbered several millions. ${ }^{1}$ Friedrich Vittinghoff suggested in passing that at least two million soldiers and their children had been

\footnotetext{
${ }^{1}$ François Jacques was a notable exception in suggesting that the overall impact of these grants was limited (Jacques and Scheid 1990: 283), though he did not attempt to quantify the total number of beneficiaries.
} 
enfranchised by the middle of the second century. ${ }^{2}$ Hartmut Wolff estimated that the army created between three and five million new citizens over the first two centuries. ${ }^{3}$ Graham Webster envisaged three million each century. ${ }^{4}$ Most recently, an article-length analysis by Alfredo Valvo implies between three and six million over the period 52-212. ${ }^{5}$ This paper proposes that these figures significantly overestimate the scale of enfranchisement. Perhaps more provocatively, it contends that they also exaggerate the degree of uncertainty. I will argue that we can be confident that the total number of new citizens created by the army between 14 and 212 was somewhere between 0.9 and $1.6 \mathrm{~m}$.

This paper makes three advances on past attempts to quantify enfranchisement. First it includes consideration of the fleets and legions, whereas previous estimates have considered the auxilia alone (and still over-estimated the overall scale of enfranchisement). Second, it takes account of the fact that the rate of enfranchisement must have fluctuated considerably over the course of the two centuries as, for example, the manpower of the auxilia expanded by around 50 per cent or when grants to auxiliaries' children were discontinued in 140. All previous estimates have been based on extrapolation from a notional annual average - usually based on the situation in the mid-second century, when the rate of enfranchisement must have been at a peak - and fail to take account of these developments. Third and most importantly, it offers a rigorous accounting of the uncertainties involved. The exercise of quantification entails working with input quantities that range from those that can be estimated with reasonable precision (e.g. the nominal strength of the auxilia in the early second century) to the highly uncertain (e.g. the manpower of the fleets). This paper uses probability as a measure of uncertainty in order to quantify how the uncertainties surrounding the input quantities affect the uncertainty about the overall scale of the phenomenon. The goal is not just to provide a best estimate of the number of beneficiaries but also to quantify how uncertain it is.

Part I reviews what is known about grants of citizenship to soldiers, with particular attention to the uncertainties that remain. Part II examines the state of knowledge about the

\footnotetext{
${ }^{2}$ Vittinghoff 1952: 15-16.

${ }^{3}$ Wolff 2007: 371.

${ }^{4}$ Webster 1998: 279.

${ }^{5}$ Valvo 2012. His estimate of 5.0-8.4 million new citizens includes the effect of natural population growth at 0.5 per cent p.a. Excluding natural growth, his assumptions - a constant rate of 3-5,000 veterans p.a., each enfranchised with two sons and four grandsons, over a period of 160 years - imply a total of 3.4-5.6 million beneficiaries over the period.
} 
three most important variables for any attempt at quantification: the manpower of the auxilia, fleets and legions, the proportion of soldiers who survived to discharge and the number of children they had. Part III presents a mathematical model of enfranchisement and interprets the results.

\section{THE ARMY AND CITIZENSHIP}

\section{BEFORE CLAUDIUS}

The practice of granting citizenship to foreigners who fought for Rome goes back to the Republic. ${ }^{6}$ But these were discretionary grants by magistrates, the antecedents of viritane grants by the emperors. This probably remained the norm even after Augustus re-organised the non-citizen forces into a permanent formation. It is widely assumed that the enfranchisement of auxiliaries and classici (men in the fleets) did not become regular practice until the reign of Claudius, though there remains some scope for doubt on this count. ${ }^{7}$ It was certainly Claudius who introduced the practice of issuing beneficiaries with bronze diplomas. ${ }^{8}$ That innovation may well have been linked to the introduction of a new system of regular grants. It would be consistent both with a wider Claudian programme of reforms to the army and with Claudius' later reputation for being overly generous with Roman citizenship. ${ }^{9}$

Nevertheless, it is clear from epitaphs that some auxiliaries were granted citizenship by Claudius' predecessors. ${ }^{10}$ On the other hand, we know of at least ten cases (including three

\footnotetext{
${ }^{6}$ Marius enfranchised two cohorts of Umbrians for bravery in the war against the Cimbri (Val Max. 5.2.8). Pompey Strabo granted citizenship to thirty Spanish cavalrymen for service in the Social War (ILS 8888).

${ }^{7}$ So Nesselhauf 1936: 148; Birley 1938; Alföldy 1968b: 225; Saddington 1975: 188-90; Holder 1980: 46-8; Birley 1986; Beutler 2007: 7; Haynes 2013: 49. A few scholars admit the possibility of widespread enfranchisement before Claudius: Vittinghoff 1952: 97; Brunt 1971: 242-3; Wolff 2007: 357.

${ }^{8}$ The earliest known diploma dates to 52 (CIL XVI 1). Given the low survival rate of diplomas from the JulioClaudian period, they may have been introduced a few years earlier. Beutler 2007:12 suggests the year of Claudius' censorship, 47/48.

${ }^{9}$ Thomas 2004 connects the introduction of diplomas and regular grants of citizenship to a broader Claudian programme of reforms to the army. On Claudius' reputation, see especially Sen. Apocol. 3.3 and Cassius Dio 60.17.5.

${ }^{10}$ Beutler 2007: 12-14 catalogues 23 C. and Ti. Iulii who were probably auxiliaries granted citizenship by Augustus, Tiberius or Gaius.
} 
discharged veterans) of soldiers who had served well over twenty-five years and yet did not have citizen-form names. ${ }^{11}$ Perhaps the most poignant example is Nertus son of Dumnotalus, a Gaul serving in the Ala Hispanorum I who appears to have been discharged as a peregrine after 36 years of service. ${ }^{12}$ There is clearly no question before the reign of Claudius of automatic enfranchisement after twenty-years of service.

It is nonetheless striking that most known veterans from the Julio-Claudian period do have citizen-form names. ${ }^{13} \mathrm{We}$ cannot rule out the possibility that, even under the first three emperors, most soldiers who survived to discharge did receive a grant of citizenship. In this case, the irregular pattern visible in the epitaphs would be the result of variation in the timing of the grant and the well-established variability of service length before Claudius (when some soldiers apparently served as long as fifty years while others were discharged after just twenty-five). ${ }^{14}$ Nevertheless, the predominance of citizens among known veterans may just be an artefact of the epigraphic habit, if citizens were more likely to be commemorated with a Roman-style inscribed stone grave marker. The conventional view that only a small proportion of soldiers could expect to benefit may well be correct. But it cannot be taken for granted.

Further uncertainty surrounds the treatment of classici and children. Given the absence of evidence of enfranchised classici before Claudius, it is possible that any grants were limited to the auxilia in this period. As for dependents, soldiers may have received conubium and citizenship for their children (as later beneficiaries did), but it is also possible that they only received personal grants of citizenship (as republican precedent suggests). ${ }^{15} \mathrm{In}$ short, the scale of enfranchisement before Claudius remains highly uncertain. ${ }^{16}$

\footnotetext{
${ }^{11}$ Holder 1980 Tables 4.1 and 4.2. For other possible examples see Alföldy 1968b: 222 and Birley 1986253.

${ }^{12}$ CIL iii $10514=$ ILS 2529 with Holder 1980: 47.

${ }^{13} 14$ ( 82 per cent) of a sample of 17 veterans dated to the Julio-Claudian period by Holder 1980 (Tables 4.1 and 4.2) appear to be Roman citizens (though this will include some men discharged after Claudius' introduction of diplomas).

${ }^{14}$ Holder 1980: 46-7.

${ }^{15}$ Pompey Strabo's famous grant to Spanish cavalrymen who served in the Social war made no provision for kin (ILS 8888).

${ }^{16}$ For the purposes of the model in Part III, I date Claudius's reform (if there was one) to 48, the date of his censorship, though it may have been as late as 52. In the interests of simplicity, I aggregate the various uncertainties involved - the proportion of auxiliaries who received a grant before they were discharged, how long they had to wait for a grant (conceivably much longer than twenty-five years), whether classici received grants, whether grants extended to children - into a single measure of the scale of the pre-Claudian regime
} 


\section{THE CLAUDIAN SYSTEM}

We are relatively well informed about grants to the auxilia and fleets from the $50 \mathrm{~s}$ thanks to the introduction of diplomas. These small bronze diptychs were issued to benefitting soldiers to document their privileges. ${ }^{17}$ The diplomas were inscribed with copies of the imperial constitution that effected the grant along with the name of the beneficiary and any wife and children for whom they claimed benefits.

The normal grant formula specifies that soldiers had to serve at least twenty-five years to qualify. ${ }^{18}$ But this was a minimum and some soldiers - we do not know how many - had to wait several years longer. ${ }^{19}$ Since auxiliaries regularly served terms of at least thirty years under Claudius (they had served even longer under his predecessors), grants were initially made to soldiers while still in service. ${ }^{20}$ The average term of service seem to have shortened further under the Flavians and there was a gradual shift to making the grant at discharge. The development can be traced in the evolution of the grant formula. Until c. 90, all grants are to serving soldiers ('qui militant'). The next two decades see the appearance of mixed grants to serving soldiers and veterans ('qui militant ... item dimissis') and a few grants to veterans alone ('qui militaverunt'). From c. 110 grants to veterans become the norm. ${ }^{21}$ Since a fixed

relative to the theoretical maximum scenario if it was identical to the Claudian regime (i.e. if all auxiliaries and classici who survived twenty-five years received citizenship for themselves and their children). The most likely value of 20 per cent represents the consensus view that grants were probably relatively infrequent before Claudius. The range 10-90 per cent reflects the very considerable uncertainty [7, f]. (Numbers and letters in square brackets refer to the assumptions in Table 2.)

${ }^{17}$ For an introduction to the form and content of diplomas, see Eck 2010: 31-5. Diplomas were issued to soldiers in the auxilia, fleets, praetorian and urban cohorts and equites singulares Augusti, but not to legionaries.

${ }^{18}$ See e.g. the eligibility clause in a typical Flavian constitution: 'equitibus et peditibus qui militant in alis sex ... qui quina et vicena stipendia aut plura meruerant quorum nomina subscripta sunt' (CIL xvi 23).

${ }^{19}$ This is implicit in the 'or more' ('aut plura'/'plurave'/'pluribusve') qualification to the twenty-five-year requirement in the grant formula. Ammonius son of Damion, a soldier of cohors I Hispanorum was apparently still a peregrine in his twenty-eighth year of service when he died in Britain in the Flavian period (RIB 2213 with Birley 1986: 256). See Holder 1980: 48-9 for other examples.

${ }^{20}$ On terms of service in the first century, see Alföldy 1968b; Holder 1980: 46-9. Terms of thirty to forty years are common under the early Julio-Claudians. Examples of men serving more than thirty years become somewhat rarer under Claudius and Nero, and more so under the Flavians (Holder 1980: 48 Table 4.1)

${ }^{21}$ Alföldy 1968; Mann 1972 (with Holder 2007: 130-1; Eck 2017: 19-20 for updated data). 
term twenty-five-year term does not seem to have become standard until the mid-second century (and even then a minority continued to served longer), postponing the grant to discharge meant that some soldiers continued to wait somewhat longer than twenty-five years for their grant. ${ }^{22}$

Auxiliaries received citizenship for themselves - if they did not already have it - and (until 140) also for their children and descendants - 'ipsis liberis posterisque eorum' in the formula of the imperial grant. ${ }^{23}$ Despite the implications of the open-ended reference to posteri ('descendants'), it is likely that the grant itself only benefitted living progeny (more specifically those named in the grant). Any children or grandchildren born after the grant would have acquired their status at conception or birth in line with Roman law. ${ }^{24}$ Wives were excluded from the grant of citizenship, but the soldiers also received a grant of conubium with a current or future wife which would ensure that any future children by that wife would be citizens. ${ }^{25}$ (In the absence of conubium, any children by a non-citizen wife would inherit

\begin{abstract}
${ }^{22}$ A term of twenty-five years does not seem to have become standard until the reign of Antoninus Pius (Visy 1995; Holder 2007: 113-116). The 'or more' qualification begins to be dropped from the formula of some constitutions from 120. But it still appears on c. 75 per cent of diplomas 120-148 and 33 per cent of diplomas post-148, showing that some auxiliaries still waited more than twenty-five years to receive citizenship (Holder 2007: 113-6; Eck 2003: 60). They were probably a small minority: only 3 per cent of 890 soldiers in cohors $X X$ Palmyrenorum in 219 had served more than twenty-five years (data from Gilliam 1965: 75). For the calculation in Part 3, the developments in the length of service and timing of the grant are represented by a schematic model in which the average term of service (i.e. the average number of stipendia served by men discharged in a given year) falls stepwise from 30-40 years in the period 14-49 to 25-30 in 50-109 (when evidence of men serving more than 30 becomes rare) and exactly 25 years by 110 (when grants to veterans become the norm, though the average is likely to remained somewhat higher for several decades). Since the estimates for 14-49 and 50-109 are clearly interdependent, they are modelled with perfect linear correlation. The model assumes that the average qualifying soldier received a grant after 25 years of service throughout the period. Some men had to wait longer, particularly in the first century, but I assume that this was a matter of at most a few years and that the effect on the overall average was relatively small. The effect of these simplifying assumptions is to slightly over-estimate the total number of beneficiaries
\end{abstract}

${ }^{23}$ See e.g. $R M D$ iv 236 : 'equitib(us) et peditib(us) ... quorum nomina subscript(a) sunt ipsis liberis posterisque eorum civitat(em) dedit et conubium cum uxoribus quas tunc habuiss(ent) cum est civitas iis data aut si qui caelibes essent cum iis quas postea duxissent dumtaxat singuli singulas'.

${ }^{24}$ Eck 2016: 123.

${ }^{25}$ The imperial constitutions restrict conubium to one woman per soldier ('dumtaxat singuli singulas', later 'dumtaxat singulis'). The formula obviously works to exclude polygamy, though this would anyway be invalid under Roman law. It may also have been interpreted to prevent the transfer of the grant of conubium to a second or further wife in the case of divorce or death (so Arnaud-Lindet 1977: 288; Phang 2001: 60). This seems 
their mother's status. ${ }^{26}$ ) It is unclear whether the grant of conubium also extended to progeny - probably the most significant gap in our knowlegde of the Claudian regime. ${ }^{27}$

The same privileges were granted to classici in the Italian and provincial fleets. Indeed the first surviving diploma was issued to a rower in the Misenum fleet. ${ }^{28}$ Unlike in many other navies, there does not appear to have been any sharp distinction between sailors, rowers and marines: all alike were classed as soldiers (milites). ${ }^{29}$ The only difference from auxiliaries was that classici had to serve a minimum of twenty-six (later twenty-eight), rather than twenty-five years. ${ }^{30}$

\section{THE CHANGE IN 140}

Grants to auxiliaries' offspring were abruptly discontinued in $140 .{ }^{31}$ The content of the grant was reduced to citizenship and conubium for the soldier alone. The picture is complicated somewhat by a small minority of later diplomas that include an additional provision (introduced 'praeterea praestitit ...') for the enfranchisement of children who had been born before their fathers enlisted. ${ }^{32}$ Variations in the wording of the provision over the period 142-206 suggest that there was a transitional period of around fifteen years in which

plausible on the analogy of the grants of conubium to soldiers in the praetorian and urban cohorts, which explicitly excluded remarriage ('dumtaxat cum singulis et primis uxoribus', e.g. CIL xvi 95).

${ }^{26}$ Gaius Inst. 1.75-80 with Kaser 1955-9: 241-2; Treggiari 1991: 45-9; Lavan forthcoming.

${ }^{27}$ It is usually assumed that the grant of conubium was limited to the soldier (Waebens 2012c: 270-1; more guardedly Phang 2001: 60). The fact that soldiers' wives are named on the diplomas, but never any sons' wives, does support this hypothesis. Yet the natural reading of the grant formula is that conubium, like citizenship, was granted to progeny as well as to the soldiers themselves - though it may well have been interpreted more narrowly.

${ }^{28}$ CIL XVI 1.

${ }^{29}$ Reddé 1986: 522-5; Saddington 2007: 212-3.

${ }^{30}$ The term of service in the Italian fleets was increased to twenty-eight years between 206 and 209 (Roxan 1994: 319 n. 6). The model in Part III assumes that classici were discharged and received their grant after twenty-six years of service, ignoring the fact that the average stipendia at discharge will have been somewhat (but probably only fractionally) longer and ignoring the increase to twenty-eight years in the final years of the period.

${ }^{31}$ The change is first attested on 13 December 140 (RMD I 39). See further Eck 2007a; Weiss 2008 ; Waebens 2012a.

${ }^{32}$ See e.g. AE 20121945 (constitution for Dacia Superior in 142): 'praeter(ea) praestitit ut liber(i) eorum quos praesidi provinc(iae) ex se antequam in castra irent procreatos probaver(int) cives Romani essent'. 
all auxiliaries were entitled to claim citizenship for children born before they entered service (presumably a small population, given an average age at enlistment around twenty), but that the exemption was soon (by the late 150s) restricted to centurions and decurions, and later extended in their case to include children born in service. ${ }^{33}$ The overall effect will have been negligible in comparison to the scale of grants before $140 .{ }^{34}$

A much more significant exception is the fact that the soldiers in the Italian fleets continued to receive citizenship for their children as before. A minor change in 158 introduced a requirement to prove that children had been born of a recognized union (perhaps to combat fraudulent declarations, though the text may merely have codified existing practice). Otherwise classici in the Italian fleets continued to receive citizenship for their children through to 212 (and indeed after). ${ }^{35}$ The situation in the provincial fleets post 140 is more obscure and has elicited conflicting interpretations. ${ }^{36}$ The picture is slowly becoming clearer thanks to the expanding corpus of diplomas (see Figure 1). ${ }^{37}$ There were between seven and ten provincial fleets in the second century. ${ }^{38}$ By 140, they were often (but not always) combined with the auxiliary units in the province in which they were based for the purposes of citizenship grants. ${ }^{39}$ Four such joint auxiliary/fleet constitutions for Pannonia

\footnotetext{
${ }^{33}$ Eck 2013: 20-3; Eck and Pangerl 2016. In the five earliest examples (from 142 to $155 \mathrm{CE}$ ), the concession extends to all soldiers. In the six others (dating from 157 to $206 \mathrm{CE}$ ) it is explicitly restricted to centurions and decurions. In three of the later examples, the requirement for children to have been born before entering service is omitted, which may just be an abbreviation or may mean that the exemption became more generous after it was restricted to officers. In the last example, a diploma of 206 , the concession is specifically for children born after the beneficiaries became officers, with no mention of children born before service.

${ }^{34}$ The very small number of children benefitting from these clauses are ignored in the model in Part III to avoid undue complication.

${ }^{35}$ The new formula replaced the old 'liberis posterisque eorum' with 'filiisque eorum quos susceperint ex mulieribus quas secum concessa consuetudine vixisse probaverint' (first attested on RMD 3 171). The formula still appears on CIL XVI 154a (249 CE), though its significance post 212 is a separate question.

${ }^{36}$ Pferdehirt 2002: 77-82: citizenship for children became a special privilege granted to a minority of classici in provincial fleets as a reward for exceptional service. Eck 2010: 46; Waebens 2012a: 14-15: all classici in provincial fleets received citizenship for their children until the 150s, when the privilege was withdrawn. 37 This updates the analysis at Pferdehirt 2002: 78. Note that the relevant section of the text does not survive in the two fleet-only constitutions post 140 (AE 20041915 and RMD V 342).

${ }^{38}$ Saddington 2007: 213-15.

${ }^{39}$ Mann 2002: 233 hypothesised that provincial fleets were issued their own constitutions until c. 99, after which they were incorporated in the constitutions for their provinces. But subsequent discoveries have undermined the hypothesis of a straightforward transition (see already Pferdehirt 2002: 76). Joint constitutions do seem to have
} 
Inferior, dating between 143 and $154 \mathrm{CE}$, include a grant of citizenship for the children of classici ('item filiis classicorum'). ${ }^{40}$ But the clause is missing from diplomas issued under joint constitutions for 145 and 157 and probably also on a constitution for 146 and another dating somewhere between 154 and $161 .^{41}$ More significantly, it does not appear on any of ten other joint constitutions attested for the provinces of Moesia Inferior, Germania Inferior, Mauretania Tingitana and Mauretania Caesariensis dating between 144 and $161 .^{42}$ It does appear on a diploma from a joint constitution for an unknown province from 151. Given the other evidence, however, this seems most likely to be from another constitution for Pannonia Inferior. $^{43}$

It is clear from the surviving diplomas that classici in Pannonia Inferior often received citizenship for their children through 154. Given the hiatuses in 145 and probably 146, it would be dangerous to assume that the absence of the formula in 157 and the diploma of 154161 indicates a permanent cessation of grants. ${ }^{44}$ It is entirely plausible that irregular grants to

become common in some provinces (notably Moesia Inferior, Pannonia Inferior and Germania Inferior), though not all constitutions for these provinces included classici and separate constitutions remained possible (e.g. in Moesia Inferior in 131-5, RMD IV 252). In other provinces, separate constitutions must have remained the norm. There is not a single attestation of a joint constitution among 45 diplomas for Syria and 40 for Britannia. ${ }^{40}$ See e.g. RGZM 30 (143 CE): 'equit(ibus) et pedit(ibus) ... item classic(is) ... quor(um) nomin(a) subscrip(ta) sunt civitat(em) Roman(am) qui eor(um) non haber(ent) item fili(i)s classic(orum) dedit'. The clause also appears on RMD IV 272 and two other copies of the same constitution (148), AE 20091826 and six other copies (152), AE 20041923 and three other copies (154).

${ }^{41}$ Missing: CIL XVI 91 (145 CE), RMD II 102 (157). Probably missing: RMD V 401 (146), RMD IV 284 (13861, probably 154-61; see Holder in RMD ad loc.).

${ }^{42}$ Moesia Inferior: RMD V 399 (145 CE), RMD IV 270 (146) [text reconstructed], RMD V 414 (c. 155), $A E$ 20071236 (157) [reconstructed], AE 20141138 (160) [reconstructed], RMD II 111 (161). Germania Inferior: Pearce and Tomlin 2018 (150), AE 20041911 (152). Mauretania Tingitana: RMD V 398 (144), AE 20051727 et al. (153). Mauretania Caesariensis: AE 20111808 (152).

${ }^{43} A E 20101272$ [reconstructed].

${ }^{44}$ Eck 2010: 46 and Waebens 2012a: 14-15 both infer a break in the 150s. Eck 2010: 46 explains the absence of the formula on some earlier diplomas by positing that it was omitted on years when no classici declared children. But the inclusion of classici in the list of units benefitting in all the cases on Figure 1 (but not on all constitutions for the province) indicates that there were at least some classici among the beneficiaries in each case. Even if the number of beneficiaries was very small, it is implausible that that there would be so many cases when at least some men were discharged but none had children, given that only a minority of soldiers failed to declare children by this period (see Part II). We should expect an average of at least 15 beneficiaries per year, assuming a force of at least 500 men (Lavan 2019b), 26 years of service, and attrition of at most 60 per 
the children of classici in Pannonia Inferior continued after the diploma evidence peters out. On the other hand, the fact that there is no provision for children on any of the joint constitutions attested for other provinces makes it extremely unlikely that the same privilege was enjoyed by all provincial fleets. It must have been limited to the Pannonian fleet and perhaps a few others. ${ }^{45}$ The Pannonian fleet was one of the smaller fleets. The three largest and hence most important for a quantitative analysis - were the British, German and Pontic fleets. ${ }^{46}$ There is unfortunately no evidence at all for the first and last of these, but the two constitutions that provided for the German fleet suggest that its soldiers were among those normally denied citizenship for their children. In sum, it seems that a minority - probably a very small minority - of classici in provincial fleets continued to receive citizenship for their children until at least 154 and conceivably through to $212 .{ }^{47}$

\section{UNIVERSALITY}

The scope of the Claudian system of grants used to be a matter of debate. Some argued that grants of citizenship remained a discretionary reward for exceptional service rather than the norm for all soldiers. ${ }^{48}$ But the rapid proliferation of diplomas has made it very hard to escape the conclusion that most units received a grant almost every year from the

cent (Part II), calculated as in Figure 6. It is hard to avoid the conclusion that that there was some inconsistency even within Pannonia Inferior.

${ }^{45}$ Waebens 2012c infers from an epikrisis document of 148 (BGU 1265 ) that veterans of the classis Syriaca were still receiving citizenship for their children, but this is not conclusive since the men receiving citizenship along with their children might rather represent beneficiaries of the praeterea praestitit clause.

${ }^{46}$ Lavan 2019 b.

47 The model allows that anywhere between 2 and 33 per cent of classici in provincial fleets received citizenship for their children post 140, most likely 8 per cent [47]. The minimum represents a scenario in which only the classis Pannonica benefited and the exception was abolished in 154 (assuming relative strengths as per Lavan 2019b). The maximum represents a scenario in which 33 per cent of all soldiers benefitted (even higher than the 25 per cent of constitutions in Figure 1 that contain the formula 'item filiis classicorum') and continued to do so through to $212 \mathrm{CE}$. The most likely value reflects either the classis Pannonica alone benefitting for the whole period or a third of all soldiers benefitting through to $154 \mathrm{CE}$

${ }^{48}$ See especially Dušanić 1982 and Dušanić 1986. 
90s through the 160s. ${ }^{49}$ There remains however, some room for doubt for the earlier first and later second centuries, because of the relative paucity of diplomas from those periods (Figure 2). ${ }^{50}$ The number of diplomas per decade rises rapidly from the reign of Claudius to the $90 \mathrm{~s}$ and then more gradually through to the 160s. There follows a complete hiatus from 167/8 to 177 (illustrated indicatively in Figure 2), after which diplomas resume at a much lower rate.

The fall-off in diplomas after 167 has drawn the most attention. Two explanations enjoy wide currency, neither of them convincing. Some cite an increase in the proportion of citizens serving in the auxilia, but that should have produced a gradual decline, not a sudden drop. ${ }^{51}$ Others suggest that the reform of 140 reduced the value of diplomas, leading fewer soldiers to request one thereafter, but this ignores the fact that diploma volumes continue to grow for at least three decades after the reform. ${ }^{52}$ With the growing volume of diplomas, however, it has become clear that the complete hiatus that lasted c. 167-177 was the result of administrative decision to discontinue the issuance of diplomas, presumably related to the exigencies of the Antonine plague and the German wars. Continuity in the witness lists that attested to the validity of each diploma indicate that grants nonetheless continued in this period; they were probably documented on some more perishable medium. ${ }^{53}$ The extremely low volume of auxiliary diplomas thereafter (up to the last known example in 206) is probably also related to this temporary measure. Peter Weiss and Michael A. Speidel have recently suggested that Commodus resumed production of bronze diplomas but limited them to the Roman units and Italian fleets and that auxiliaries were henceforth issued diplomas only if they paid for them (which would explain why auxiliary diplomas slow to a trickle rather than ending altogether). ${ }^{54}$ Again, continuity in the witness lists suggests that auxiliaries continued to receive the customary grant, which must normally have been recorded on

\footnotetext{
${ }^{49}$ Eck 2016: 121-2; Wolff 2007: 357. Dietze-Mager 2007 presents what she sees as certain cases of auxiliaries being discharged without citizenship in late second-century papyri, but all her examples admit other interpretations.

${ }^{50}$ This Figure is based on the diploma corpus in n. 140.

${ }^{51}$ Phang 2001: 78; Wesch-Klein 2007: 442; Gallet and Le Bohec 2007: 269.

52 Greenberg 2003: 415; Haynes 2013: 84. Link 1989: 17 already noted the implausibility of any link to 140.

53 The outer side of each diploma displayed the names and seals of seven witnesses who attested to the validity of the copies of the imperial constitution inscribed on it. From $138 \mathrm{CE}$, diplomas for auxiliaries, classici and equites singulares were witnessed by a standing panel of seven persons who were always listed in order of seniority (Eck 2012a: 43). For the continuity in witness lists between 167 and 177 see Eck, MacDonald and Pangerl 2003: 374-5; Eck 2012a: 46-9.

${ }^{54}$ Weiss 2017: 145-9; Speidel 2015: 58.
} 
ephemeral documents of the type introduced in 167. It thus seems likely, but not certain, that the Claudian system continued through to 212.

The expansion in diploma volumes over the period 50-160 has received far less comment. A small part can be explained by the expansion of the auxilia over the period (part II), more if it is assumed that soldiers at first waited considerably longer than twenty-five years to receive a grant (meaning that fewer would survive to qualify). The expansion may also reflect changing behaviour on the part of diploma recipients: increased demand for diplomas (though the hypothesis that they were elective remains controversial) or an increase in the proportion of veterans settling in the Danubian provinces that have produced a disproportionate share of diplomas. ${ }^{55}$ But it remains possible that it took several decades before all soldiers could be confident of receiving a grant if they survived long enough. ${ }^{56}$

\section{GRANTS ANTE EMERITA STIPENDIA}

In exceptional circumstances, soldiers could secure citizenship before having satisfied the normal requirement of twenty-five or twenty-six years of service. Some early examples are known from the Julio-Claudian period and the civil war of $68-70 .{ }^{57}$ At some point probably under the Flavians - there emerged a regular practice of rewarding auxiliary units for outstanding service by making a block grant of citizenship ante emerita stipendia to serving soldiers. Two cases are documented by diplomas. ${ }^{58}$ In 106 Trajan rewarded the soldiers of cohors I Brittonum milliaria Ulpia for their service in the Dacian war by granting them citizenship, without any provision for children or grant of conubium (both presumably

\footnotetext{
${ }^{55}$ Roxan 1986 and Roxan 1989 suggested (on the basis on the over-representation of equites among known diplomas recipients) that diplomas were optional and had to be purchased. For the contrary argument that diplomas were normally issued to all eligible soldiers/veterans, see Eck 2013: 12; Gallet and Le Bohec 2007: 268.

${ }^{56}$ Pferdehirt 2002: 18, 25; Beutler 2007: 11. Both envisage that it took more than 50 years for grants to become near universal. Link 1989 infers that grants to the fleet did not become regular until Hadrian (but assumes regular grants for auxiliaries). In the interests of economy, the model in Part III ignores the possibility that grants may have been less frequent before 90 or after 167.

${ }^{57}$ See Tac. Hist. 3.47.2 on a cohort incorporated from the army of the Pontic kingdom in 63, CIL XVI 10-11 for former classici invalided out of legio II Adiutrix in 70 and RMD IV 205 for soldier discharged ante emerita stipendia from the Ravenna fleet in 71.

${ }^{58}$ A similar grant can be inferred from $A E 2008$ 1736, though the grant formula does not survive. See Eck and Pangerl 2008: 348-53.
} 
delayed until the usual time) ${ }^{59}$ In 120 Hadrian rewarded the cavalrymen of ala Ulpia contariorum by enfranchising them together with their fathers, mothers, brothers and sisters. ${ }^{60}$ That was an act of extraordinary largesse and probably represents a unique reward for some extraordinary service performed by the $a l a .{ }^{61}$ The first grant probably represents the norm for these special awards. Only a small minority of units ever benefitted from such a grant - the approximately 15 per cent of units that are attested with the epithet $C$ (ivium) $R$ (omanorum). ${ }^{62}$ And the main effect of a block grant would be to redistribute enfranchisement in time, bringing forward the enfranchisement of soldiers (but not their children) by on average a dozen years. So the impact on the overall rate of enfranchisement would have been modest. ${ }^{63}$

Early enfranchisement has also been hypothesised for both the Italian fleets and the (much smaller) equites singulares Augusti. In both cases the hypothesis was invoked to explain an onomastic anomaly. In the second century, all known classici in the Italian fleets have citizen-form names (tria nomina), even though they continued to be recruited from the same peripheral areas - notably Thrace and Egypt - as before. Similarly all known equites singulares have citizen-form names (and around 75 per cent have the gentilicium of the emperor reigning at the time of their enlistment). ${ }^{64}$ Three possible explanations have been proposed: (i) recruits were granted Roman citizenship; ${ }^{65}$ (ii) they were given a personal grant of the Latin right; ${ }^{66}$ or (iii) they were given new names in the Roman style, but their legal status remained unchanged. ${ }^{67}$ The first hypothesis seems least likely. It is hard to reconcile with the fact that constitutions issued specifically for the Misenum and Ravenna fleets always provide for the enfranchisement of the soldiers themselves - like constitutions for auxiliaries

\footnotetext{
${ }^{59}$ CIL XVI 160.

${ }^{60} A E 20101858$ and four other exemplars.

${ }^{61}$ Eck and Pangerl 2003.

${ }^{62}$ Maxfield 1981: 227. See further Holder 1980: 32-4.

${ }^{63}$ These block grants are ignored in the model in Part III.

${ }^{64}$ Speidel 1965: 61-4.

${ }^{65}$ Proposed for the fleets by Mann 2002: 232-3; Dana 2013: 228 and for the equites singulares by Kraft 1951: 69-73; Speidel 1965: 61-7; Raepsaet-Charlier 2001: 431-3.

${ }^{66}$ Proposed for both formations by Mommsen 1881: 467-73 and endorsed for the fleets by Alföldy 1966: 52-4; Forni 1968; Pferdehirt 2002: 172; Marotta 2014: 12-15 and for the equites singulares by Grosso 1966; Pferdehirt 2002: 173-7; Marotta 2009: 70; Eck and Pangerl 2015: 259.

${ }^{67}$ Proposed for fleets by Starr 1941: 71-4; Kienast 1966: 26; Mócsy 1986: 442-5; Reddé 1986: 526-8; Salomies 1996: 169 and for the equites singulares by Mócsy 1986: 445-6; Stylow 1994.
} 
and provincial fleets and unlike those for the citizen units in Rome. This remained the case even after significant revisions were made to the text of the grant formula for fleet constitutions in the $150 \mathrm{~s} .{ }^{68}$ It has also emerged recently that the grants for the equites singulares were identical to those for auxiliaries, and not like those for the citizen units in Rome. ${ }^{69}$ On the other hand, Mommsen's hypothesis of personal grants of the Latin right has been weakened by evidence that the citizens of Latin communities continued to use peregrine names rather than the tria nomina and doubt that Latin status was ever granted to free-born individuals as opposed to communities. This leaves the third hypothesis looking most likely. There is good evidence that some peregrines who enlisted in the army took or were given citizen-style names without having been awarded Roman citizenship. ${ }^{70}$ In any case, even if these soldiers did receive citizenship at enlistment, the effect would only be to advance a small number of grants by twenty-five years. ${ }^{71}$

\section{CITIZEN AUXILIARIES}

The auxilia were nominally the non-citizen branch of the army, with citizens serving in the legions. Even under Augustus, however, there were some auxiliary units that were

\footnotetext{
${ }^{68}$ See the new formula on RMD 3171 (158 CE).

${ }^{69}$ Stylow 1994. Stylow thought that he could prove that the beneficiary of RMD 3158 was a peregrine on the grounds that no wife or child was named - and hence that the diploma would have had no value if he were a citizen. But the grant of conubium could have been of value in a future marriage. Nevertheless, the formula of the constitution does make it unlikely that all equites singulares were Roman citizens.

${ }^{70}$ Conclusive evidence is rare because names are usually the only evidence for status. The best examples, all from Egypt where the documentation is richest, are (i) a man previously known as Neilos who served in legio XXII Deiotariana as L. Pompeius Niger, but did not receive Roman citizenship until after discharge (P. Thomas 6 with Waebens 2012b: 137); (ii) Iulius Martialis, a soldier in ala I Thebaeorum, who died in 115 while still in service (hence before he could normally have benefitted from a grant of citizenship), who is said to have been called Isidoros before enrolment (M.Chr. 372 IV); (iii) Octavius Valens, still serving in an auxiliary cohort in 142, who had Alexandrian but apparently not Roman citizenship (M.Chr. 372 IV-V); iv) C. Iulius Apolinarius, another serving soldier in ala I Apamenorum in 159-60, who was named [--]os s. of Mystos before service (M.Chr. 239); and (v) a man recorded in the census of 159 who had been known as G. Valerius Capito when he was in service, but then reverted to his original name Ptolemy (SB 2215337 with Bagnall 1993). For further evidence, see Lesquier 1918: 219-24 and Wolff 1976: 307-11.

${ }^{71}$ Accordingly these uncertainties are ignored in the model in Part III, which assumes that soldiers in the Italian fleets and equites singulares received citizenship after twenty-six/twenty-five years of service.
} 
composed exclusively of citizens. ${ }^{72}$ They would have accounted for 7-11 per cent of all auxiliaries in $14 .{ }^{73}$ The representation of citizens in other units increased significantly over the following two centuries. Indeed, it is sometimes suggested that citizens had all but completely displaced peregrines by the end of the second century. ${ }^{74}$ If true, this would have significant implications for the overall scale of enfranchisement (though citizen auxiliaries should still have stood to gain citizenship for any children born from a union with a peregrine woman). ${ }^{75}$ But it is almost certainly an exaggeration.

Some cite the near disappearance of auxiliary diplomas after c. 167 as evidence for the displacement of peregrine recruits, but the fall in diploma volumes is too abrupt to be the result of a secular development like the spread of citizenship. Others note the addition of the qualification 'qui eorum non haberent' ('[to] those who did not have [it]') to the grant formula in auxiliary diplomas in 140, but that change cannot convey any quantitative information about the scale of citizen recruitment. ${ }^{76}$ Better evidence can be found in Konrad Kraft's study of auxiliary epitaphs from the Rhine and Danube. Kraft found that the representation of citizens grew from 7 per cent in the Julio-Claudian period to 38 per cent under the Flavians and Trajan, 51 per cent from Hadrian to c. 170 and 96 per cent in the later second and third centuries. ${ }^{77}$ But Kraft's final category - with its striking figure of 96 per cent - includes men who died after Caracalla's grant and so cannot give a reliable picture of the situation in 170-212. He also relied on the duo nomina as an index of citizen status,

\footnotetext{
72 Augustus raised up to 46 cohorts composed entirely of Roman citizens, many of them in response to the Pannonian and German revolts. 22-25 of these survived as permanent formations. As many as 7 more were raised under the Flavians or Trajan. Though they were apparently not de iure closed to peregrines, epitaphs suggest that they continued to draw their recruits almost exclusively from citizens well into the second century. See Holder 1980: 64-9.

${ }^{73}$ Assuming 22-25 quingenary units (see above) and a total nominal strength of 110-160,000 men (Part II).

${ }^{74}$ See e.g. Le Bohec 1989: 97-8; Wesch-Klein 2007: 442; Rocco 2010.

${ }^{75}$ It is worth noting that it remains possible, but unlikely, that auxiliaries who were already citizens did not benefit at all from the imperial grants. A single auxiliary constitution, for the province of Dalmatia in 94 (CIL XVI 38), limited the grant, including citizenship for children and conubium, to soldiers who could prove they were peregrines ('qui peregrinae condicionis probati erant'). On balance it seems likely that this unparalleled exclusion of citizen auxiliaries was an isolated (but still unexplained) exception rather than that it makes explicit what was otherwise a tacit norm.

${ }^{76}$ For the change to the formula, see e.g. $R M D$ v 404 (Dacia, 151): 'equit(ibus) et pedit(ibus) ... quor(um) nom(ina) subscr(ipta) sunt civit(atem) Roman(am) qui eor(um) non hab(erent) dedit'.

${ }^{77}$ Kraft 1951: 80-81, tabulated by Le Bohec 1989.
} 
although we now know that some non-citizens used the duo and even tria nomina form, especially in the army ${ }^{78}$ His analysis is also vulnerable to distortion if citizens were more likely to receive Roman-style funerary commemoration than non-citizens. His figures may thus over-estimate the representation of citizens in the Rhine-Danube region.

In any case, military records reveal a very different situation in the east. ${ }^{79}$ At most 35 per cent of 93 equites in the ala veterana Gallica in Egypt in 179 were citizens, as were at most 30 per cent of 100 men who joined cohors XX Palmyrenorum at Dura Europus in the two decades before $212 .^{80}$ Nor can the difference be ascribed merely to a distinction between west and east. We lack good global data, but the equites singulares - recruited across all auxiliary alae - offer a potentially useful check. Michael P. Speidel observed that 75 per cent of 365 soldiers who were discharged from the equites singulares between 132 and 145 have the gentilicium of the emperor reigning at the time of their enlistment. ${ }^{81} \mathrm{He}$ proposed that these were peregrines who had adopted citizen-style names when they were enrolled in the unit. The suggestion is plausible, independent of whether the name change was accompanied by a grant of citizen status (as Speidel thought). If he is right, at most 25 per cent of these men were citizen recruits - just half of the level in Kraft's sample of men who died between 117 and 170. Caution is clearly in order. There was a significant increase in the scale of citizen recruitment over the period, but peregrines may well have remained a significant proportion of auxiliary recruits as late as $212 .^{82}$

\footnotetext{
${ }^{78}$ See n. 70.

79 Already noted by Roxan 1986: 278-9.

${ }^{80}$ P. Hamb I 39 with Meyer's note ad loc. and P. Dura 98 with Gilliam 1965: 81-4.

${ }^{81}$ Speidel 1965: 61-2.

82 The model in Part III assumes that the representation of citizens among auxiliary recruits grew from 7-11 per cent in 15 (22-25 quingenary cohorts civium Romanorum in a total nominal strength of 110-160,000 men, assuming the number of citizens in other units was negligible) to $20-50$ per cent in 140 (the upper limit being Kraft's figure for Rhine-Danube epitaphs in 117-170; the minimum set just below Speidel's data for equites singulares recruited 102-12) and 45-80 per cent in 212 (assuming a representation of 50-100 per cent in western units and $~ 30$ per cent in eastern units, with a 70:30 west-east split in auxiliary forces - see Holder 2003: 145; Eck 2012c: 88-90) [4]. Given the very large uncertainties for 140 and especially 212, I do not specify most likely values and instead model these as uniform distributions. The estimates are clearly interdependent with each other and also with the estimate for the displacement of peregrines by citizens among legionary recruits [13]. (The higher the representation of citizens among auxiliary recruits in 212 , the higher the reduction we would expect in peregrine recruitment to the legions). All four quantities are therefore modelled with a perfect linear correlation. As for the fleets, it assumes that all recruits were peregrines throughout the period. The
} 


\section{CITIZENSHIP AND THE LEGIONS}

Service in the legions was notionally exclusive to Roman citizens. The norm can be seen, for example, in Cassius Dio's habit of referring to the legions as 'the citizen formations' ( $\tau \grave{\alpha} \pi 0 \lambda \imath \tau \imath \kappa \grave{\alpha} \sigma \tau \rho \alpha \tau o ́ \pi \varepsilon \delta \alpha){ }^{83}$ But it is clear that the norm was often broken during major conflicts. The wars of 68-70 offer several examples. Two legions (I and II Adiutrix) were raised from the peregrine soldiers in the Italian fleets. ${ }^{84}$ A similar measure might explain an anomalous Domitianic constitution granting conubium and other privileges to veterans of $X$ Fretensis who had been enrolled in 68 and 69, when the legion was fighting in the Jewish War. ${ }^{85}$ There is also some circumstantial evidence for the extraordinary recruitment of men from peregrine communities in Syria and Gaul in this period. ${ }^{86}$ Massive losses during the Bar Kochba revolt of 132-5 again elicited exceptional measures. The veterans discharged from $X$ Fretensis (stationed in Jerusalem) in 150 included 22 men who had been transferred from the Misenum fleet by Hadrian, probably to replace losses in the revolt. ${ }^{87}$ A spike in diplomas for the Misenum fleet in 160 (for men recruited in 134, most of them Thracians) reveals that there was a mass levy of Thracians in 134 to replenish the fleet, presumably because a significant number of its trained soldiers were transferred to the legions in Judea to replace losses there. ${ }^{88}$

The recruitment of peregrines may also have been a regular practice in peacetime in units that had difficulty sourcing enough citizen recruits - most plausibly the eastern legions in the first century. Giovanni Forni's 1953 monograph on legionary recruitment remains the

\footnotetext{
universal use of tria nomina in the Italian fleets severely restricts the scope for study of the legal status of recruits, but the zones of recruitment - predominantly Egypt and Thrace - suggest that the majority were peregrines. The simplifying assumption that they were all peregrines will tend to overestimate the total number of beneficiaries.

${ }^{83}$ See e.g. 46.46.6, 52.25.6, 53.15.1, 55.23.1 and 73.14.13 [Xiph.].

${ }^{84}$ Reddé 1986:509-10.

${ }^{85}$ ILS 9059 with Forni 1953: 105. See below for the question of regular grants to legionary veterans.

${ }^{86}$ Mann 1983: 52; Mann 2000: 159-60.

${ }^{87}$ PSI ix 1026 with Mann 2000: 156.

${ }^{88}$ Eck 2007b: 33-6; Eck 2013: 18.
} 
only detailed study of the scale of the phenomenon. ${ }^{89} \mathrm{He}$ concluded that peregrines were recruited in significant numbers under Augustus and Tiberius, but only in the east, and that they became a rarity by the second century at the latest. ${ }^{90}$ More recent discussions have essentially relied on his assessment of the scale of peregrine recruitment. ${ }^{91}$ But the consensus view that peregrine recruitment was a local and transient phenomenon might be mistaken, since Forni's methodology was relatively conservative. For the period before Claudius, he relied on origin as an index of status, assuming that only legionaries who originated in a nonRoman community can have been peregrine recruits. ${ }^{92}$ But his analysis conflated Roman and Latin communities in the west, ignoring the possibility that recruits from the latter might have been peregrines. For the period after Claudius, he focussed instead on soldier's gentilicia. $\mathrm{He}$ posited that the only plausible candidates for enfranchised peregrines were men whose gentilicium was that of the emperor reigning at the time of their recruitment, and found they were a small minority. ${ }^{93}$ But newly enfranchised recruits did not necessarily take the emperor's name. Indeed, the one incontrovertible case of a peregrine recruit to the legions certainly did not. L. Pompeius Niger, a native Oxyrhynchite who was granted citizenship by Claudius after discharge from legio XII Deiotariana. ${ }^{94}$ Expanding the focus to other possible indices of peregrine origin, such as the tribe Pollia or the origo castris (whose function remains obscure) would increase the proportion of possible peregrine recruits, indicating that the regular recruitment of peregrines may have continued into the second century - and not just in the east. Further study is needed, but it is important to remain open to the possibility that the legions were and remained a route to citizenship for significant numbers of peregrines. ${ }^{95}$ It is often asserted that any peregrine recruits were granted citizenship before

\footnotetext{
${ }^{89}$ Forni 1953: 103-15. Forni 1974 provides additional data and analysis on legionaries' homes, but does not expand on the earlier analysis of peregrine citizen recruitment beyond some brief remarks on methodology at 252-3 and 347.

${ }^{90}$ Forni 1953: 110 and 113

${ }^{91}$ Mann 1983: 49 and 51-2; Waebens 2012b: 138.

92 Forni 1953: 108-10.

${ }^{93}$ Forni 1953: 111-15.

${ }^{94}$ P. Thomas 6 with Rathbone 2001: 105.

${ }^{95}$ Given my concerns that Forni may have underestimated the scale of this phenomenon, the model in Part III incorporates considerable uncertainty on this count. It allows for the proportion of peregrine recruits in 15 being anywhere between 5 per cent (corresponding to 10 per cent in the eastern legions and 0 per cent in the rest) and 25 per cent (corresponding to 50 per cent in the eastern legions and 10 per cent in the rest), modelling this as a uniform distribution [13]. The development of peregrine recruitment over the next two centuries is represented
} 
being enrolled, but in at least some cases - such as Pompeius Niger - the grant was delayed to the end of their service. ${ }^{96}$

There is further uncertainty as to whether legionaries normally received the other privileges that auxiliaries and classici did. ${ }^{97}$ Most studies have concluded that it is unlikely that legionaries normally received conubium and even less likely that they normally received citizenship for any existing children. ${ }^{98}$ There are two strong arguments for this position. First, we know from diplomas issued to men in the praetorian and urban cohorts that they received conubium but not citizenship for any non-citizen children. It would be surprising if soldiers of those elite units were denied a privilege that was normally granted to legionaries. Second, legionaries never received diplomas. Even if they only received conubium, one would expect them to have received the same official confirmation that was issued to praetorians and urbaniciani (not to mention auxiliaries and classici). On the other hand, there are several reasonably secure cases of legionary veterans who received conubium and/or citizenship for their children. ${ }^{99}$ But they are all very close in date - mostly Domitianic - so they may well

by a schematic model of linear decline from the specified level in 15 to some fraction of that level by $212 \mathrm{CE}$, with the uncertain quantity being the percentage decline over the period [14]. On the conventional view (ultimately based on Forni), the recruitment of peregrines was essentially a first-century phenomenon. But it remains possible that it continued to play a significant role in the second century. Again, the model admits considerable uncertainty by allowing for an overall reduction of anywhere between 0 and 100 per cent and modelling this as a uniform distribution. Since this quantity is obviously related to the level of citizen recruitment to the auxilia, I include perfect linear correlation between [14] and [4].

${ }^{96}$ Waebens $2012 \mathrm{~b}$ proves that at least some, and conceivably all, peregrine recruits were enfranchised at discharge. For the model in Part III, I assume that all peregrine recruits were enfranchised on enlistment [i]. For the purposes of estimating attrition, I assume that the term of service in the legions (i.e. stipendia at discharge) rose from twenty to twenty-five years in 100 [h], though the increase may have occurred somewhat earlier (Scheidel 1996: 121) and some men served an additional year because of biennial discharge. All these simplifying assumptions tend to slightly overestimate the number of beneficiaries.

${ }^{97}$ Wolff 1974: 496-509; Phang 2001: 61-75; Wolff 2007: 359-66.

${ }^{98}$ Valvo 2003; Wolff 2007: 360-5; Dietze-Mager 2007: 76-83. Vittinghoff 1986 posits a grant of conubium alone. Phang 2001: 61-75 is agnostic. The model in Part III allows for the possibility that peregrine recruits to the legions received citizenship for their children at discharge. The probability of 25 per cent represents a belief that it is possible, but unlikely.

${ }^{99}$ A veteran of XXII Deiotariana could cite an edict of Domitian that granted him conubium and probably also citizenship for his children (P. Mich. 432 with Wolff 1974; Wolff 2007: 364). Another veteran of the same legion seems to have enjoyed conubium with a peregrine woman, again thanks to Domitian (P. Ryl. with Wolff 1974). M. Valerius Quadratus, a veteran of X Fretensis secured citizenship for three children and apparently also 
represent a temporary departure from the norm. ${ }^{100}$ If legionaries were denied privileges that were granted to otherwise less-privileged auxiliaries, it was probably because the nonrecognition marriage was interpreted more strictly with regard to nominally citizen units.

\section{OTHER FORMATIONS}

The auxiliary cohorts and alae were permanent formations with relatively regular terms of service. But the Roman emperors continued to raise other units that might be irregular in unit size, organisation and/or terms of service. These are conventionally referred to as the numeri. ${ }^{101}$ It is a matter of debate whether veterans of these units received any of the privileges of auxiliaries and classici. We have diplomas from three constitutions for soldiers in numeri. ${ }^{102}$ But these are unit-specific grants that seem to be rewards for exceptional service rather than normal practice. It is notable that they merely enfranchise the soldiers without providing for children or conubium, as auxiliary grants do. Moreover, soldiers serving in numeri are never included in the constitutions for the provinces in which they served, as classici in provincial fleets were. It seems increasingly unlikely that veterans of the numeri received exactly the same privileges as auxiliaries and classici, as some early theories proposed. ${ }^{103}$ While it remains possible that they regularly received citizenship for themselves alone (as the recipients of the surviving diplomas did), the balance of the evidence supports $\mathrm{J}$. C. Mann's hypothesis that even those grants were a rare exception. ${ }^{104}$ In any case, the numeri

\footnotetext{
conubium, again by a grant of Domitian (ILS 9059; the edict quoted seems to have been specific to a group of veterans, rather than of general application, as is sometimes suggested). Iulius Sabinus, who was serving in III Cyrenaica in 96, had two children who appear to be citizens by a non-citizen wife (Tasoucharion), though it is not clear whether they were born before or after discharge (P Mich. viii 465 and 485 with Alston 1995: 134-5). There are also the clearly exceptional cases of the men discharged from I and II Adiutrix, which were hastily raised from the fleets in the civil wars of 68-69, in 68 and 70 respectively.

${ }^{100}$ Wolff 1974: 496-509 suggests possible explanations for exceptional treatment in each case.

101 Callies 1964; Southern 1989; Reuter 1999.

${ }^{102}$ RMD I 17 (for Palmyreni sagittarii in Dacia Superior in 120) and RMD I 27 (for the same in 126), CIL XVI 158 (for Mauri equites in Moesia, date uncertain)

103 Rowell 1939; Vittinghoff 1950: 402-3.

${ }^{104}$ Mann 1954, followed by Le Roux 1986: 367-70; Southern 1989: 105-6; Haynes 2013: 70. Reuter 1999: 385 is agnostic.
} 
were a relatively late development and remained a small fraction of the size of the auxilia in 212 , so even regular grants would not have a significant effect at the aggregate level. ${ }^{105}$

Soldiers in the praetorian and urban cohorts did receive bronze diplomas at discharge, like auxiliaries and classici, from the 70 s at the latest. ${ }^{106}$ But they only received conubium, never citizenship for any non-citizen children. Despite two recorded cases in which it was discovered that some men serving in the praetorian cohorts were in fact peregrines, there is no reason to suppose that service in these units was a route to citizenship for significant numbers of peregrines. ${ }^{107}$ These must have been exceptional cases. ${ }^{108}$ The seven cohorts of vigiles, originally recruited primarily from the ex-slaves of the city (both citizens and Junian Latins), later recruited significant numbers of ingenui, some from as far afield as Pannonia and Egypt. ${ }^{109}$ But there is no evidence that any peregrines secured citizenship this way and men in the vigiles do not seem to have received diplomas. There was, however, a separate provision for Junian Latins. A lex Visellia (probably dating to 24) provided that they could acquire Roman citizenship by serving in the vigiles for six years; a senatus consultum of unknown date later reduced that to three. ${ }^{110}$ Again the numbers will have been too small to affect the overall scale of enfranchisement. ${ }^{11}$

\section{SOLDIERS, SURVIVORS, CHILDREN}

\footnotetext{
105 As of 1989, forty distinct 'ethnic numeri' were known (Southern 1989: Appendix 1). The majority are first attested in the third century. The full total need not have existed simultaneously, since these units were formed and disbanded more readily than regular cohorts or alae. A total of 10-40 units c. 212 with an average nominal strength of 200-500 men (Cheesman 1914: 87-8: 200-300; Southern 1989: 103-4) would represent a total of around 9,000 men. Grants to soldiers in numeri are ignored in the model in part III, to avoid undue complexity. 106 Roxan and Holder 2003: 414 n. 2; they may only have been issued to soldiers who requested them: Eck 2012b.

${ }^{107}$ CIL v 5050 (Claudius) and AE 2013 2182-4 (Hadrian) with Eck, Pangerl and Weiss 2014.

108 The model in Part III ignores any grants to praetorians or urbaniciani.

109 Sablayrolles 1996: 178-83.

${ }^{110}$ Gaius Inst. 1.32b, Tituli Ulpiani 3.1.5. Sablayrolles 1996: 38 inferred from the jurists' use of the term Latinus that the right extended to 'Latin citizens' (i.e. citizens of Latin communities and other recipients of a hypothetical personal grant of Latinitas), but the jurists always use Latinus with the specific sense of Junian Latins (Terreni 1999: 348 n. 26).

111 The vigiles are therefore excluded from the model in Part III.
} 
Any attempt at quantifying the scale of grants to soldiers and their children demands consideration of three crucial variables: the manpower of the relevant formations, the proportion of recruits who survived to receive a grant, and the average number of living children they had by that point.

\section{NOMINAL STRENGTH}

The strength - or rather the nominal strength (a qualification I will return to) - of the legions is well established. We can track the evolution of the total complement of legions from twenty-five in 14 to thirty-three in 212 with unusual precision. ${ }^{112}$ There is some uncertainty about unit strength (related to questions about the size of the strengthened first cohort and when it was introduced and about whether the legionary equites were counted among the centuries), but it is relatively small. ${ }^{113}$ Nominal strength grew from 120-123,000 in 15 to $154-162,000$ in 104 and 169-178,000 in 197.

Establishing the strength of the auxilia is more difficult. Numerous figures circulate, not all of equal merit. The best are based on the painstaking tabulation of provincial garrisons as revealed by the diplomas. The proliferation of diplomas has allowed ever better estimates for the period 100-160. The most precise is Paul Holder's figure of 218,000 for the reign of Hadrian. ${ }^{114}$ That excludes centurions and decurions, who benefitted from the imperial grants

\footnotetext{
${ }^{112}$ See Mann 1983: 160 Table 33 (rightmost column), with Jacques and Scheid 1990: 151 for 150-212. The model in Part III uses their data for the number of legions in service, ignoring short-lived additions or subtractions of one legion $[\mathrm{g}]$.

${ }^{113}$ Roth 1994; Scheidel 1996: 120-1. The model in Part III follows Scheidel in assuming 4,800-900 men in the Julio-Claudian period and 5,120-400 in the second century [12]. Since there is little to choose between the competing hypotheses for unit strength, these are represented as uniform distributions. Because of the obvious interdependence, the estimates are modelled with perfect linear correlation. The date at which reinforced first cohorts were introduced is uncertain. In any case, it cannot have been immediate and it must have taken years or even decades before all legions had fully adapted to the new organisation. This process of adjustment is represented by assuming constant linear growth in average nominal strength over the period 69-99.

${ }^{114}$ Holder 2003: 120, refined to 219,000 in 127-30 in an unpublished study based on 2011 data. (I am very grateful to Paul Holder for having shared his data.) Werner Eck's estimate of 200,000 c. 150 (Eck 2012c: 89-90) is based on an equally careful reconstruction of provincial garrisons, but works with somewhat cruder assumptions about unit strength (counting quingenary and milliary units as 500 and 1000 men respectively and making no allowance for cohortes equitatae).
} 
alongside their men, so another 4,000 has to be added. ${ }^{115}$ But even for this period, there remains some uncertainty about the precise number of units, ${ }^{116}$ nominal unit strengths, ${ }^{117}$ and the proportion of cohorts that were equitatae (i.e. had a cavalry component). ${ }^{118}$ Given these uncertainties, anything in the region 200-240,000 seems possible. ${ }^{119}$ The diplomas indicate that the complement of auxiliary units remained roughly constant through to the $160 \mathrm{~s} .{ }^{120}$ The following decades involve greater uncertainty because of the near disappearance of auxiliary diplomas. We know of a number of units that were raised after 161 (notably those with the epithets Aurelia or Septimia). Other units may have been eliminated or disbanded. But the net change is unlikely to have exceeded 10,000 men ( 20 units) by $212 .{ }^{121}$

Extrapolating back to 14 is more difficult. Holder has used the diploma evidence to reconstruct a complement of 207,000 men in 100. Including officers and allowing for

\footnotetext{
115 The total number of centurions and decurions is calculated assuming 16/24 turmae per (quingenary/milliary) ala, 6/10 centuries per cohort and 4/8 turmae per cohors equitata, as in the standard model.

${ }^{116}$ Holder counts 368 units certainly or 'probably' in existence in 127-30 (cf Eck 2012c: 89-90 for c. 362 in 150), but notes another 16 that 'possibly' existed. I allow that up to the same number of units in his probable category may not have existed, for a range of 349-387 units (36-38 of them milliary).

${ }^{117}$ Holder uses the standard model of 512 and 768 for alae quingenariae and milliariae and 480 and 800 for cohortes quingenariae and milliariae, with an additional 128/256 equites in cohortes equitatae. On the
} uncertainties, see Hassall 1983. I allow for turmae of 30-32 men in cohortes equitatae and quingenary alae and 30-40 in milliary alae. Note that I do not allow for the possibility (canvassed by Breeze and Dobson 2000: 15961; Haynes 2001: 52-3) of cohort centuries of 100 men (which would be counterbalanced by a much lower ratio of actual to nominal strength). Haynes 2001: 52-3 plausibly questions the degree of standardisation in unit organisation, but any idiosyncrasies are likely to have averaged out overall.

${ }^{118}$ Holder assumes 71 per cent, the proportion that can be inferred for the units in Syria and Cappadocia (Holder 2003: 119; so also Cheesman 1914: 168). But others have assumed lower proportions: 52 per cent (Rankov 2007: 54 and 71), 50 per cent (Birley 1981: 40-1), 40 per cent (Spaul 2000: 526). I allow for anywhere between 50 and 80 per cent.

119 The model in Part III assumes a force of 200-240,000 in 128, most likely 222,000 [3]. The most likely value is Holder's estimate, after adding officers. There is obviously considerable epistemic interdependence in the estimates for auxilia strength in different years, so they are modelled with a perfect linear correlation.

${ }^{120}$ Eck 2012c: 89-90 reconstructs a complement of 362 units in 150 (37 of them milliary), very close to Holder's 368 units in 130 (37 of them milliary).

121 The model in Part III assumes that strength remained constant from 130 to 161 and allows for a subsequent increase or decrease of up to 10,000 by 212 [3]. 
uncertainties as before gives a possible range of 193-229,000 men. ${ }^{122}$ The rarity of diplomas before 90 makes it very difficult to reproduce the analysis for earlier periods, so we have to resort to cruder methods. The limited evidence suggests a force somewhere in the region of $130-180,000$ in $70 \mathrm{CE}^{123}$ and $110-160,000$ in $14 .^{124}$

The manpower of the fleets is even more uncertain. I have argued elsewhere that a total complement of c. 25,000 is most likely, but that anything in the range $15-50,000$ is possible. ${ }^{125}$ Since several of the provincial fleets were established after 14 (though another at Forum Iulii was disbanded during the Julio-Claudian period), it may have taken the fleets some time to reach their peak strength. But the effect of any such growth is dwarfed by the uncertainty about the peak size. ${ }^{126}$ Figure 3 illustrates what we know about the strengths of the three formations, their development over the course of the period and - crucially - the varying degree of uncertainty.

${ }^{122}$ An unpublished calculation based on the data on provincial garrisons in Holder 2006 and the assumptions used in Holder 2003: 119-120. Hence the model's assumption of a force of 193,000-229,000, most likely 214,000 (Holder's estimate plus officers) [3].

${ }^{123}$ Cheesman 1914: 54-55 estimated c. 180,000 men in 69-70 on the basis of references to auxiliary units Tacitus' Histories. An alternative approach would be to work back from 100 by deducting c. 40,000 men in units we know or suspect to be Flavian additions (28 units with the epithet Flavia, 5 units incorporated from the kingdom of Commagene and 27 milliary units). This suggests a slightly lower complement of around 170,000 men. But both these estimates include c. 20,000 men in Belgica and Germania that may not have been formally incorporated into the regular auxilia until the Flavian period (Kraft 1951: 37-40, Holder 1980: 110; see contra Alföldy 1968a: 86-93). For the model, I defer to defer to Cheesman on the most likely value, while incorporating considerable uncertainty - allowing for anything between 140,000 and 190,000 [3]. ${ }^{124}$ Cheesman 1914: 53 relied on Tacitus's statement that the auxilia and legions were roughly equal in strength (Ann. 4.5.4) in his survey of Roman forces at the death of Augustus. He arrived at an estimate of c. 150,000 by assuming parity with the complement of twenty-eight legions before the German revolt. But the twenty-five that remained at the time that Tacitus was describing seems a more appropriate point of comparison. This would imply a slightly lower figure in region of 125,000 men. Working back from the estimate for 69-70 by deducting another c. 20,000 men in units known to have been absorbed from the client kingdoms during the Julio-Claudian period suggests a similar figure of 130,000 (excluding the Belgic and German units). Again the uncertainty is considerable. For the model I again defer to Cheesman for the most likely value, but allow for anything between 110,000 and $160,000[3]$.

${ }^{125}$ Lavan 2019b.

${ }^{126}$ Hence fleet strength is modelled as a static variable representing the average complement over the whole period [8]. I assume the Italian fleets accounted for roughly 50 per cent of total manpower, as per Lavan 2019b [b]. 
These totals are based on nominal unit strengths. Actual strength must have been significantly lower. Even under the best conditions, it is hard for armies to maintain manpower at nominal strength due to variability in loss and recruitment. The few scholars who have addressed this phenomenon in the Roman context have variously suggested ratios of $90-95$ per cent, c. 90 per cent and c. 80 per cent. ${ }^{127}$ There is a small documentary corpus against which these hypotheses can be tested. Strength reports and other lists that give the actual strength of a unit at a point in time make it possible to calculate the ratio of actual to nominal strength in each case, given our assumptions about nominal unit strengths (Table 1).

The two highest ratios are both associated with Cohors XX Palmyrenorum, in two strength reports around three years apart. This poses two problems. First, the relatively high ratios may represent exceptional reinforcement in the face of an Eastern threat. ${ }^{128}$ But we should be wary of discounting outliers as anomalous when the sample is so small. More problematic is the distorting effect of counting the same unit twice. For the purposes of estimating the overall average, I count it once at the average of two strength ratios (107 per cent). The average across the remaining seven cases is 89 per cent, in line with the estimates of MacMullen and Scheidel. But the sample is small and the variance high, so we should not have too much confidence in that point estimate. The average strength ratio for all units across the whole period could have been anywhere between 81 and 96 per cent. ${ }^{129}$

\section{ATTRITION RATES}

Quantifying the number of beneficiaries of imperial grants requires an estimate of the proportion of soldiers who survived twenty-five years of service. Survival here is a question not just of mortality but also of discharge due to illness or injury (missio causaria) or misconduct (missio ignominiosa) - either of which would normally deny the soldier a grant of citizenship. A figure of c. 50 per cent has often been used as a rule of thumb, but the

\footnotetext{
${ }^{127}$ MacMullen 1980: 454: 90 per cent; Scheidel 1996: 120-1: 90-95 per cent (in 'the orderly times of budgetary affluence under Hadrian and Antoninus Pius'); Bang 2013: 419: 80 per cent.

128 Hassall 1983: 99-100.

${ }^{129}$ This is the 95 per cent confidence interval for the population average. It is a function of the size and variance of the sample. It does not take account of any biases in the surviving data points. The model in Part III assumes that the average ratio of actual to nominal strength was 81-96 per cent, most likely 89 per cent [1].
} 
subject has been put on a new footing by Walter Scheidel's study of attrition rates in the legions. ${ }^{130}$ (It is worth observing that there is no significant difference in the age profile of recruits between the legions and auxilia, once a correction is made for age rounding. ${ }^{131}$ ) Scheidel estimated the effective twenty-five-year attrition rate in the legions at c. 55 per cent by inferring the normal annual complement of veterans discharged from a legion from several inscribed lists of soldiers discharged from a legion in a particular year. ${ }^{132}$ More recent work has revealed that the total number of veterans on one of the four laterculi Scheidel relied on was significantly higher than originally thought. Taking this into account would reduce the implied attrition rate to just under 50 per cent. ${ }^{133}$ But the sample is very small. We are not yet in a position to rule out an attrition rate as high as 60 per cent (closer to the rates Scheidel observed among the Roman units, which he attributed to the effect of excess mortality in the city) $)^{134}$ or as low as 40 per cent (an optimistic estimate of the actual mortality rate among men of similar age in the civilian population $)^{135}$ - a range corresponding to an average

\footnotetext{
${ }^{130}$ Scheidel 1996: 117-32.

${ }^{131}$ Scheidel 1996: 100 observed a mean age at recruitment of 20.8 among legionaries $(\mathrm{N}=523)$, falling to 20.3 after correcting for age rounding. Based on the data on Julio-Claudian auxiliaries in Holder 1980: 138-9
} (combined with data from his prosopography), I calculate a mean age at recruitment of $21.6(\mathrm{~N}=191)$, falling to 20.6 after correcting for age rounding (using the same method).

${ }^{132}$ Scheidel 1996: 119-24. Scheidel dismissed three outliers as anomalous and observed that the remaining four cases cluster around 120 veterans per year (c. 100, 120, c.125, c.120) which he took to be the normal discharge rate in peacetime. He compared this to an assumed average effective strength of c. 4,800 to infer the attrition rate.

${ }^{133}$ Mirković 2004: 214 updates the data in Scheidel's Table 3.12. The annualised total for V Macedonica in 134 is increased from c. 100 to 150 , raising the average of the four 'normal' cases from c. 120 to c. 130 per year. Assuming an effective strength of 4,800 and linear attrition (as in Scheidel), this implies a twenty-five-year attrition rate of 48 per cent (calculated from the formula in Figure 6; see online Appendix 2b).

${ }^{134}$ Using the same approach, Scheidel 1996: 124-9 infers a 17-year attrition rate of 58 per cent for praetorians (which would imply a twenty-five-year attrition rate of 72 per cent at a constant annual rate of loss) and a 20year attrition rate of 60 per cent for equites singulares (implying a twenty-five-year survival rate of 68 per cent) 135 Coale Demeney Model West Level 4 Male $\left(\mathrm{e}_{0}=25.3\right)$ gives a 40 per cent twenty-five-year attrition rate for men aged 20 (Scheidel 1996: 117-124). Other models imply higher attrition: The more widely used Level 3 Male $\left(\mathrm{e}_{0}=22.9\right)$ gives 42 per cent (Frier 2000: 789). Level 2 Male $\left(\mathrm{e}_{0}=20.4\right.$, favoured by Bagnall and Frier 1994: 34) gives 45 per cent, while the tables in Ulpian imply 44 per cent (Frier 1982). Recent work suggests that the Coale Demeney tables underestimate mortality at this stage of life (ages 15-49) (Woods 2007). 
discharge rate of 110-145 men per legion per year. ${ }^{136}$ It is worth noting that this is an estimate of the average attrition rate in normal conditions and does not take account of excess mortality during major wars. But the effect of such spikes in mortality on the overall average survival rate, across all units and two centuries, was probably modest. ${ }^{137}$

\section{CHILDREN}

The third crucial variable is the average number of living children soldiers had when they received their grants. It is now well established that the so-called 'marriage ban' - better understood as non-recognition of marriage - did not prevent soldiers from forming unions and raising children. ${ }^{138}$ It is also clear from epitaphs that the rate of family formation rose significantly from the first century into the second in all formations, probably due to increasing stability of service. ${ }^{139}$ The development can be observed most clearly for auxiliaries, since the diplomas name any offspring to whom citizenship was granted. In the surviving diplomas, the average number of children declared is close to zero in the 70s and 80 s, begins to increase rapidly in the 90s and 100s and peaks at around 2.1 in the 110s and 120s before declining slightly in the decade before the abolition of grants to children in 140 (Figure 4). ${ }^{140}$ There is insufficient data for the 50s and 60s to determine with any confidence whether they resembled the 70 s and 80 s or whether the latter represented a transient

\footnotetext{
${ }^{136}$ Calculated as in Scheidel 1996: 121-2, assuming an average effective strength of 4,800 men. The model in Part III assumes an average twenty-five-year attrition rate of 40-60 per cent, most likely 40 per cent [2].

137 Scheidel 2007: 427-8.

138 Jung 1982; Phang 2001; Scheidel 2007 ('non-recognition’); Speidel 2013.

${ }^{139}$ Most formations and regions studied show significant increases in the proportion of soldiers commemorated by kin rather than fellow-soldiers. See Phang 2001 Chapter 6 and Appendices 3 and 8.

${ }^{140}$ The analysis is based on the diplomas published in CIL XVI (including the Supplementum), RMD I-V, $R G Z M$ and $A E$ 2002-15 (the last published volume constituting the cut-off point), after excluding 65 texts that were superseded by later editions. Of the remaining 1095 diplomas, there are 224 that (i) were issued to auxiliaries (or classici in provincial fleets, under a joint constitution) (ii) can be securely assigned to a decade from the 50s and 130s and (iii) on which the number of children is known or can be reconstructed based on the number of lines and layout of the section. Where the number of children named on a line of the diploma is uncertain, possible children are counted as 0.5. (Omitting diplomas where children were declared but the precise number is uncertain would tend to underestimate the average number of children, since diplomas declaring no children would be over-represented in the sample). The data is available online as Appendix 1. For more general discussion of family relations as revealed by the diplomas, see Greene 2015 and Juntunen 2018.
} 
depression in the rate of family formation due to the shock of the civil wars of $69-70 .{ }^{141}$ In any case, the increase beginning in the 90 s and 100 s coincides with a reduction in the frequency of redeployment and an increase in local recruitment, both of which are likely to have facilitated the formation and durability of families. ${ }^{142}$ Even at its peak in that period, however, auxiliaries' rate of social reproduction by the time of their discharge was probably somewhat lower than that of their peers in the civilian population. ${ }^{143}$

Although the diploma data is relatively rich by the standards of Roman history, there remains some uncertainty about the actual average number of children. The sample data may well be biased. The most likely source of bias is the significant over-representation in the diploma corpus of men who served in the Danubian provinces. ${ }^{144}$ This probably works to over-estimate the overall average, since soldiers in other regions appear to have had fewer children. ${ }^{145}$ Even discounting the possibility of bias, the high variance in the number of children and relatively small sample sizes mean that we could not be confident that the sample means are precise estimators of the population means (see the breadth of the 95 per cent confidence intervals for the inferred means in Figure 4). Nevertheless, the data is of sufficient resolution to show chronological change on a scale that demands to be taken into account in any quantification of citizenship grants. ${ }^{146}$

\footnotetext{
${ }^{141}$ Juntunen 2018 suggests that the low levels of the 70s and 80s were a transient anomaly caused by the displacement of some units during the Jewish revolt and civil wars.

142 On these wider processes, see Phang 2001: 154-8; Scheidel 2007: 420-1; Haynes 2013: 77

${ }^{143}$ I use the term social reproduction to acknowledge the fact that the diplomas only capture children for whom soldiers requested citizenship. Since they omit children that soldiers fathered but abandoned and children they raised but for whom they did not seek citizenship, the diplomas must underestimate their rate of biological reproduction. Richard Saller's microsimulations of kin sets provide a potential baseline for comparison.
} Assuming a life expectancy at birth of twenty-five and an average age at first marriage of twenty for women and thirty for men, his simulations predict 2.4 living children and grandchildren for the average man of 45 years (Saller 1994: 51).

${ }^{144}$ In my corpus, 69 per cent of 623 auxiliary diploma recipients whose region of service is known served in the Danubian provinces, though those provinces accounted for just 38 per cent of all auxiliary forces in the second century (calculated from the data in Holder 2003).

${ }^{145}$ In diplomas from the period 117-40, an average of 2.6 children are reported for soldiers serving in the Danubian provinces $(\mathrm{N}=45)$, compared to 2.3 for the African provinces $(\mathrm{N}=10)$ and 1.0 for the East $(\mathrm{N}=12)$. Earlier periods show the same pattern.

146 The model in Part III deploys a simple model of the development of family size in which the average number of children starts off low $(0.26+/-0.22)$ in the Julio Claudian and Flavian periods and then grows in linear fashion over the period 96 to 117 to reach a much higher rate $(2.0+/-0.43)$ that is maintained through the reigns 
The sample of diplomas issued to soldiers in the Italian fleets is too small for analysis by decade, but still sufficient to demonstrate significant divergence from auxiliaries (Figure 5). ${ }^{147}$ The average number of children starts off at a similarly low rate in 50-95 but grows much more slowly through the second century (even after the discontinuation of grants to auxiliaries' children), only just exceeding 1.0 after Caracalla's grant. ${ }^{148}$ The meagre evidence for soldiers in the provincial fleets suggests that they were more like auxiliaries among whom they served than the other classici in Italy. ${ }^{149}$ The analysis cannot be extended to the legions since legionaries did not receive diplomas. ${ }^{150}$

\section{CONUBIUM}

The grants of conubium enabled veterans of the auxilia, fleet and Roman units (and possibly also the legions) to marry non-citizen women and still pass on their citizen status to their children. In theory, this could have facilitated rapid growth in the citizen population, since the number of citizens in benefitting families could have doubled in a single generation if all veterans married peregrines and had on average two children who survived to adulthood. In reality, however, the overall impact of conubium must have been much more limited. First, many veterans married citizen women, often the daughters of other soldiers,

of Hadrian and Antoninus Pius, before dropping to 0 in 140 (on the assumption that the aggregate effect of the praeterea praestitit clauses was negligible) [6]. The ranges for the two steady-state periods are set to encompass the 95 per cent confidence interval calculated for the average number of children in those periods from the sample data (indicated with error bars in the figure). Since the estimates for 14-95 and 117-140 are clearly related to each other and also to the estimates of children of classici in the Italian fleets [10], all these quantities are modelled with a perfect linear correlation

${ }^{147}$ My sample of 1160 diplomas includes 106 issued to the Italian fleets, of which 99 can be securely dated to one of my periods; in 56 of those the number of children is known or can be reconstructed.

${ }^{148}$ As for auxiliaries, the model in Part III uses a schematic model of the evolution of family size from a relatively low level in 50-95 (0.26 +/- 0.22, as for auxiliaries) through a period of linear growth in 96-116 to a higher level $(0.79+/-0.37)$ that is maintained from 117 through to 212 [10]. The estimates for 117-212 are based on the mean and 95 per cent confidence interval for the number of children on fleet diplomas from 117 to $250(\mathrm{~N}=46)$.

${ }^{149}$ My sample includes just 8 examples, scattered across eight decades from 79 to $157 \mathrm{CE}$, with an average of 1.5 children declared. For the purposes of the model in Part III, I assume that classici in provincial fleets had as many children as their counterparts in the auxilia and that there was no change after 140 [11].

150 The model assumes that legionaries had the same number of children as auxiliaries, and that this remained constant after 140 [j]. 
with the result that the grant of conubium proved redundant. ${ }^{151}$ Second, even those who did marry peregrine women probably did not have enough children to replace themselves in the next generation. The diplomas show that even in the mid-second century auxiliaries tended to have somewhat fewer children than we would expect for men of their age. The gap is even more pronounced in the first century, and among classici. It is possible that veterans were able to make up the deficit after discharge, enabling them to replace themselves in the next generation, but this is far from evident, given that the youngest would have been in their mid$40 \mathrm{~s}$

Third, conubium must be understood in the wider context of citizen soldiers' capacity to reproduce themselves both biologically and as citizens. The surplus citizen children created by conubium were offset by a deficit of citizen children due to the depressed rate family formation among citizens who enrolled in the army. I estimate that 1.2-1.8 million Roman citizens were recruited to the auxilia and legions over the first two centuries CE. ${ }^{152}$ Although many of them did have children during service, it is clear that they had fewer than the norm for men of their age. While it is possible (but unlikely) that those who survive to discharge were able to make up the deficit in subsequent years, 40-60 per cent died before they could do so. Moreover, some of the children they did have as serving soldiers would have been born to peregrine women: they would be born peregrines and would remain so if their fathers died before they could benefit from an imperial grant. As such, these citizen recruits' rate of social reproduction as citizens (determined by the average number of citizen children who survived to adulthood) would have been even lower than their already depressed rate of biological reproduction (determined by the average number of children who survived to adulthood). These 'missing' citizen children of citizen soldiers will have offset most or all of the surplus citizen children produced by the minority of veterans who made use of the grant of conubium by marrying peregrine women. Quantification is complicated by the uncertainty about whether legionaries normally received conubium, whether the grant of conubium extended to a soldier's children and what proportion of citizen veterans formed unions with peregrine women. ${ }^{153}$ These are complex questions that demand a separate study.

\footnotetext{
${ }^{151}$ Phang 2001: 138 and 331-2; Greene 2015.

152 The estimate is based on the model and assumptions in Part III.

${ }^{153}$ With regard to the significant uncertainty as to whether the grant of conubium extended to children, it is worth noting that conubium would only allow male children to transmit their status to children of mixed unions. The effect of conubium is that children take the status of their father, so the child of a citizen mother and noncitizen father would not be a citizen even with conubium (Gaius Inst. 1.77). In a milieu where most veterans'
} 
But it seems prima facie unlikely that the indirect effects of conubium could have made up for the relatively modest impact of direct grants diagnosed by this paper.

\section{QUANTIFICATION}

\section{A MATHEMATICAL MODEL}

It should by now be clear that an adequate estimate of the scale of enfranchisement cannot afford to focus on the auxilia alone but must include the fleets and should also take account of the legions. Nor is it acceptable to rely on extrapolation from an estimate of the scale of enfranchisement at a single point in time. The annual rate of grants must have varied massively over the course of two centuries between Augustus and Caracalla, given on the one hand the regularisation of grants by Claudius, the growth in the size of the auxilia and the parallel reduction in the length of service, the increase in the rate of family formation and, on the other, the growth in the representation of citizens in the auxilia (and concomitant decline in the recruitment of peregrines to the legions) and the end of grants to children in 140.

To simulate the effects of these developments on the annual volume of grants, I will model grants on a year-by-year basis for the period from 14 to 212 for each of the three formations. The mathematical model is available online and the assumptions are tabulated in Table 2 (which I refer to with numbers or letters in square brackets). ${ }^{154}$ Several variables for which there is no evidence of long-term trends - such as the ratio of actual to nominal strength and the attrition rate - are modelled as static, i.e. with a constant value representing the average over the period. Any year-to-year variation in these variables is ignored on the assumption that it is stochastic and hence cancels out at the level of the model as a whole.

For the auxilia, the model starts from estimates of total nominal strength at several specified points $(14,69,99,128,161$ and 212) [3]. It extrapolates to all intervening years, assuming constant linear growth between fixed points, and then calculates actual strength each year given an assumed ratio between actual and nominal strength (modelled as a constant) [1]. The model proceeds to estimate the number of recruits each year from 15 to

children married non-citizens, conubium for children - if it existed - would merely ensure that a cohort of citizen children would produce roughly as many citizens in the next generation. It could not drive significant growth in the citizen population.

154 The model is available online as Appendix 3, with a description in Appendix 2a. 
212 inclusive. ${ }^{155}$ It does so on the basis of assumptions about the twenty-five-year attrition rate (a constant) [2] and the term of service in the year in question (decreasing stepwise over the period) [5], using a simple model of recruitment, attrition and discharge. This calculates the number of recruits as a function of total strength $(N)$, length of service $(t)$ and total attrition between recruitment and discharge $\left(a_{t}\right)$ (Figure 6). ${ }^{156}$ This allows the model to calculate the number of recruits needed to replace losses over the past year. Focusing on attrition alone would underestimate recruitment, especially in the first century, since additional recruits were required to supply the gradual increase in the strength of the auxilia (Figure 3). So the model adds sufficient recruits to supply any increase in formation strength from the previous year. ${ }^{157}$ The model then calculates the number of each cohort of recruits who were peregrines given an additional assumption about the prevalence of citizenship among recruits (which grows linearly between defined points, as with nominal strength) [4].

These annual cohorts of peregrine recruits provide the basis for estimating (given the attrition rate [2] again) the number of auxiliaries who qualified for a grant twenty-five years later. $^{158}$ (In other words, the model captures the fact that it took twenty-five years for changes in recruitment to affect the volume of grants. ${ }^{159}$ ) Given a further assumption about the average number of children per qualifying soldier (which increases stepwise over time) [6], the model estimates the number of enfranchised children and hence the total number of grants each year. A scaling variable [7], which represents actual grants as a proportion of the theoretical maximum, is used to calculate the number of grants before Claudius' reform, which is dated to 48 .

\footnotetext{
155 The fixed points are defined as the end of the year in question, so the model covers the period between 31 December 14 to 31 December 212.

156 The model assumes that (1) soldiers are recruited and discharged at the same time each year, (2) total strength is $\mathrm{N}$ on that date, (3) attrition proceeds by a fixed decrement (i.e. number of men lost) rather than constant rate (following Scheidel 1996: $123 \mathrm{n}$. 85), and (4) attrition over periods close to but not equal to $t$ can be extrapolated from $a_{t}$. The derivation of the formulae in Figure 6 is available online as Appendix $2 \mathrm{~b}$.

${ }^{157}$ The model ignores a few cases of reductions in strength. The circumstances under which legions ceased to exist remain obscure. See Wilkes 2002: 534-5.

${ }^{158}$ Since my focus is on the capacity of the army to contribute to the conversion of peregrines into citizens, I do not count grants to the children of soldiers who were recruited as citizens. Any children they had with peregrine women would have been born peregrines, so the grant would be efficacious in their case. But this would merely be mitigating one aspect of the negative effect of military service on citizen recruits' capacity to reproduce themselves as citizens (as discussed with regards to conubium), not creating additional citizens.

${ }^{159}$ For simplicity, recruitment in the twenty-five years before 15 is assumed to be equal to that in 15 .
} 
Grants to classici are modelled in the same way, except that formation strength is represented as constant [8] because of the considerable uncertainty (the constant representing average strength over the period), all recruits are assumed to be peregrine [c], soldiers are assumed to serve 26 years [d, e] and the number of children is modelled separately for the Italian and provincial fleets $[10,11]$ to allow for the relatively low rates observed in the former. For the legions, the model starts from the number of legions in service $[\mathrm{g}]$. This is multiplied by average unit strength [12] (which increases over the course of the second half of the first century) to calculate nominal strength for each year. The model then calculates annual cohorts of recruits and veterans as with the auxilia and fleets. It also calculates the number of recruits who were peregrines, given assumptions about how this proportion evolved over the period $[13,14]$. It assumes that all peregrine recruits were enfranchised on enlistment; it also allows for the possibility that they received citizenship for any peregrine children born in service when they were discharged [15], assuming that legionaries had the same number of children as auxiliaries [j].

'All models are wrong, some models are useful. ${ }^{, 160}$ One key element of model-design is identifying the right level of complexity. I have attempted to identify the key variables and uncertainties while omitting relatively minor details that would greatly increase the complexity of the model without significantly affecting the overall result. The model ignores grants to the numeri and Roman units, ante emerita stipendia grants to auxiliary units and the (unlikely) possibility of early enfranchisement for soldiers in the Italian fleets and/or the equites singulares. These omissions will tend to slightly underestimate the number of beneficiaries, but the effect should be offset by the fact that the model also ignores spikes in mortality during major wars, the effect of some men waiting longer than the minimum period to receive their grant, the fact that some peregrine recruits to the legions received citizenship at discharge rather than enlistment and the possibility that some auxiliaries were discharged without grants before 90 and/or after 160. The effects of these omissions should be individually small and should partly cancel out at the aggregate level.

\section{UNCERTAINTY}

There are obviously many uncertainties involved, some concerning details of the systen that remain obscure, others related to our imperfect knowledge of relevant historical

\footnotetext{
${ }^{160}$ Box 1987: 202.
} 
quantities. This is not in itself an obstacle to quantification, because uncertainty can be quantified. The relevant question is how much uncertainty there is about the overall scale of enfranchisement. I will argue that the wide ranges that have been reported by the few scholars who have tackled the question exaggerate the degree of uncertainty (as well as overestimating the scale of enfranchisement).

Uncertainty can be quantified using probabilities. In the Bayesian or subjective interpretation of probability, all uncertainties are subjective in the sense that they arise from the limits of the knowledge of a particular observer. They can all be quantified with probabilities, which represent the observer's degree of belief in different possibilities, given the information available to them. ${ }^{161}$ These probabilities are subjective, in the sense that they reflect the limits of knowledge rather than any objective randomness in the world. They are also conditional, meaning that they depend on a state of knowledge: they will change in response to new discoveries or new interpretations of existing data. Finally they are personal, in the sense that they reflect a particular observer's assessment of the evidence (as do all historical judgements). Your probabilities for the various uncertainties may not match mine, but the model provides a framework in which to aggregate your probabilities, if they are very different. Uncertainty and subjectivity are ubiquitous challenges for quantification in ancient history. Most estimates of historical quantities contain considerable uncertainty and they are always grounded in a particular historian's inferences from the limited information available. Two of the great merits of the Bayesian framework are that it incorporates uncertainties into the analysis and acknowledges the subjectivity that is inherent in the process of estimation, rather than treating these as points of weakness to be obscured by a misleading rhetoric of certainty and objectivity. Understood in this Bayesian framework, probability emerges as an ideal tool for representing and manipulating the epistemic uncertainties - i.e. uncertainties arising from the limits of our knowledge - that loom so large in ancient history. Indeed, probability is arguably the only way to manage uncertainty: 'If you want to handle uncertainty, then you must use probability to do it, there is no choice.' 162

\footnotetext{
${ }^{161}$ Lindley 2006 and Spiegelhalter 2011 are accessible introductions to the Bayesian conception of uncertainty and probability. Buck, Cavanagh and Litton 1996 is a more formal presentation aimed at archaeologists. The idea of using subjective probabilities to represent epistemic uncertainty in history is discussed briefly in Lavan 2016 and in more detail in Lavan 2019a.

${ }^{162}$ Lindley 2006: 239.
} 
Almost all the relevant uncertainties concern the actual value of historical quantities, such as the proportion of auxiliary recruits who were citizens in $15 .{ }^{163}$ In these cases, the uncertainty is represented by a probability density function over possible values, with the probabilities representing the historian's degree of belief in the various possibilities. In most cases, I use a Triangle distribution to assign probabilities. The Triangle distribution is a mathematical distribution whose shape is determined by three parameters corresponding to the minimum, most likely and maximum values. It is commonly used to represent epistemic uncertainties in forecasting and risk analysis. ${ }^{164}$ Figure 7 illustrates the use of a Triangle distribution to represent the uncertainty about the nominal strength of the fleets (Variable [8] in Table 2). It incorporates my beliefs both about what value is most likely and about how wide a range of values is possible. It offers a good approximation to how my degree of belief in different possible values falls away from the most likely value towards the minimum and maximum values and can easily accommodate any asymmetry (as here, where the plausible range extends further above the most likely value than it does below it). It is also computationally straightforward since its shape is determined by three parameters with an intuitive interpretation. In a few cases of very high uncertainty, where I can identify a range of possible values but not a most likely value or region, I use a uniform distribution, which assigns an equal probability to all values in the range. A corresponding Uniform distribution is illustrated for comparison on Figure 7. Note that the area enclosed by a probability density function always sums to 100 per cent.

Table 2 lists the beliefs that underlie my estimate. By 'belief' I mean set of evidencebased probabilistic judgements about uncertain quantities. ${ }^{165}$ These are represented schematically by minimum, maximum and (where possible) most likely values for each quantity, which determine the Triangle (or Uniform) probability distributions used in the model. The table also notes a small number of interdependencies, a problem I will return to. Since the idea of assigning probabilities to uncertainties may appear outlandish on first

\footnotetext{
163 The one exception, the uncertainty about whether discharged legionaries normally received a grant of citizenship for peregrine children born before discharge, concerns the truth of a hypothesis. In probability theory, this is an uncertain 'event' ('event' being used as a generic term for any proposition that may be true or false). Uncertainty about an event can be quantified by a single probability representing the observer's degree of belief that the proposition is true, given the information available. On uncertain events as opposed to uncertain quantities, see Lindley 2006: 12 and 137.

164 Vose 2008: 403; Morgan and Henrion 1990: 96.

165 On this sense of 'belief', see Lindley 2006: 12-13.
} 
acquaintance, it is worth reiterating that the purpose is not to estimate an objective probability that exists in the world, but rather to represent the uncertainty about the historical quantity. The probabilities are only 'a language in which we express our state of knowledge or state of certainty'. ${ }^{166}$ Seen in this light, it is easier to produce a probability distribution for the value of an uncertain quantity than to venture a precise estimate.

The next step is to calculate the implied probability distribution for the total number of new citizens by propagating these probability distributions through the model. This is done through Monte Carlo simulation. This involves generating a very large number of random scenarios using the probabilities established by Table 2, calculating the number of new citizens (and any other quantity of interest) in each scenario, and observing the distribution of values across all scenarios. This can be imagined as a process of sampling from the almost infinite number of possible pasts. As the sample size increases, the observed distribution of outcomes will converge on the shape of the underlying probability distribution. Figure 8 shows the frequency distribution after 50,000 iterations. This probability distribution represents what I should believe about the level of enfranchisement, given the beliefs in Table 2. For the purposes of discussion, I will reduce this probability distribution (and those for other quantities of interest) to two summary statistics: the expected value and the 95 per cent credible interval. The expected value is the mean of the Monte Carlo simulation. This represents the probability-weighted average of all possible values and is the best point estimator of the quantity of interest. ${ }^{167}$ The 95 per cent credible interval is the shortest range of possible values that includes 95 per cent of the probability mass. ${ }^{168}$ It represents the range of what is plausible, after discounting the least likely values in the tails of the distribution.

\section{RESULTS}

Tables 3 and 4 present a selection of the results of the simulation, rounded to the nearest thousand. Note that there is no rounding within the model, where precision is

\footnotetext{
166 Kaplan 1993: 141.

${ }^{167}$ On 'expected value' in probability theory, see e.g., Buck, Cavanagh and Litton 1996: 99; Vose 2008: 159; Lindley 2006: 137-9.

${ }^{168}$ On Bayesian 'credible intervals' (to be distinguished from a frequentist confidence intervals, which do not admit a probabilistic interpretation, see O’Hagan et al 2006: 234-5.
} 
essential. ${ }^{169}$ For each quantity, the tables report both the expected value and, in brackets, the 95 per cent credible interval. ${ }^{170}$ Table 3 presents snapshots of key annual flows, such as the number of recruits, veterans and benefitting soldiers, for each formation in five different years. It illustrates the considerable variation over the two centuries studied here. For example, the number of recruits to the auxilia (row a) must have almost doubled from c. 6,000 in 15 to c. 10,000 in 139 as nominal strength increased from roughly 150,000 to 220,000 and service length decreased from more than thirty to around twenty-five years. Past estimates have been erratic in their assumptions about total strength and attrition and potentially misleading in focusing on a particular moment in time. ${ }^{171}$

The number of auxiliary veterans (b) discharged each year grew even more steeply, from c. 1,800 to c. 5,200 men per year, as the effect of increasing recruitment was accentuated by falling attrition due to earlier discharge. (Note that the recruitment effect is lagged, since the number of veterans discharged in a given year depends on the number of men recruited several decades earlier, not those recruited in the current year.) The number of enfranchised soldiers (c) is lower because some of the veterans were recruited as citizens (in 50 this is partly offset by the fact that soldiers received the grant several years before discharge). The credible interval for 15 is particularly wide, reflecting the uncertainty about the scale of grants before Claudius. Including children, the total number of beneficiaries (e) grew from c. 3,400 at the outset of the Claudian regime to c. 10,000 on the eve of the reform

\footnotetext{
169 'To go, with the valid help of mathematics, from approximate premises to approximate conclusions, I must go by way of an exact algorithm, even though I consider it an artifice.' (De Finetti 1989: 204, a quotation I owe to Daniel Jew).

${ }^{170}$ Note that credible intervals cannot be simply summed because they represent probability distributions. The probability distribution of the sum of two (or more) probability distributions has to be calculated by simulation. ${ }^{171}$ Jacques and Scheid 1990: 142 estimated 10-18,000 auxiliary recruits pa for a total strength of 150-225,000, but this implies an implausibly high attrition rate of more than 80 per cent over twenty-five years of service. Haynes 2001: 63 estimated around 10,500 auxiliary recruits for a strength of 215,000 men, without allowing for formations being under strength, but also implicitly assuming relatively low attrition of 38 per cent; the two biases roughly cancel each other out. Scheidel 2007: 432 suggested in passing an annual total of c. 7,500 recruits for the 'various auxiliary formations', but that was based on an assumption that they were roughly equal to the legions (though the auxilia and fleet were together at least 50 per cent larger than the legions in the second century). Eck 2012c: 88-91 estimated c. 9,000 recruits pa for the auxilia and fleet together, assuming a total strength of 230,000, but this implies no attrition at all. This brief survey should illustrate the need for figures to be grounded in plausible estimates of both effective strength and attrition. In any case, Table 3 demonstrates the danger of generalising from an estimate for any single point in time.
} 
of 140 (driven by simultaneous growth in the number of qualifying soldiers and the average number of children, despite an increase in the recruitment of citizens over the period), before dropping to c. 2,300 thereafter (after grants to auxiliaries' children were discontinued).

Changes in the legions were more modest, because the effect of the significant increase in manpower in the later first century (with growth in both the number of legions and unit strength) was largely offset by an increase in the length of service. Hence recruitment (i) in 100 should not have been not significantly higher than in 15 (the increase in 212 reflects the expansion to 33 legions under Severus). The number of veterans (k) probably fell slightly in the second century, due to the higher attrition associated with later discharge. I have not attempted to model similar developments for the fleets, given the much greater uncertainty about formation size. But the number of citizenship grants (h) should have increased substantially between 15 and 140 due to an increase in average family size, before falling to a lower level (when only the Italian fleets and a minority of the provincial fleets continued to benefit from grants to children.)

Table 4 reports the total number of grants by formation and period. We know enough about the auxilia to be able to estimate the number of persons granted citizenship with reasonable precision. Between 0.4 and 0.7 million peregrine soldiers received citizenship from 15 to 212 (a). They were supplemented by another 0.2-0.4 million children of peregrine recruits (c), for a total of 0.6-1.1 million persons enfranchised (c) - a fraction of what most previous scholarship has suggested. There are significant uncertainties involved but they are encompassed within this range, which includes 95 per cent of all the possible scenarios implied by the assumptions in Table 2 . Though usually ignored, the fleets also made a significant contribution, not least because soldiers in the Italian fleets continued to receive citizenship for their children after 140 . They added approximately a third to the contribution of the auxilia: 0.1-0.3 million beneficiaries over the whole period (f). The auxilia and fleets together produced a total of $0.8-1.3$ million citizens over the whole period. The contribution of the legions is much more uncertain, spanning more than an order of magnitude, from a few tens of thousands to a few hundred thousand $(\mathrm{g})$. But the contribution to the uncertainty about the overall scale of enfranchisement is relatively small. Combining all three formations, 0.91.6 million peregrines received citizenship by imperial grant (h). Just under a third, 0.2-0.5 m, of the beneficiaries were children (i).

\section{CAVEATS}


The probability distributions summarised in Tables 3 and 4 are - it bears repeating - a representation of uncertainty, not estimates of some objective probabilities. They should be understood as an attempt to provide a careful and reasoned assessment of the current state of our knowledge. They depend on my understanding of the structure of the problem (as encoded in the selection of relevant variables and the mathematical model of the relationship between them) and on my assessment of what is known about the historical value of those variables (as specified in Table 2). These assessments can and should be interrogated. The model can be used to test the impact of different assumptions on the overall result.

Given the large number of variables involved, it is worth bearing in mind that they do not have equal weight in the analysis. Figure 9 shows the results of a sensitivity analysis in which the relative importance of the variables is evaluated by measuring the impact on the output (the number of new citizens) of increasing each variable (and any dependent variables) from its minimum to its maximum value, while keeping other variables at their mean value. ${ }^{172}$ The variables related to the prevalence of citizens among auxiliary and legionary recruits $[4,14$ and 13] rank high on this measure. So do those related to family size [6, 10 and 11] and the attrition rate [2]. These are the areas where new evidence, or new interpretations of existing evidence, would have the greatest impact on the estimate of the overall scale of enfranchisement. The nominal strength of the fleets [8], the ratio of actual to nominal strength [1] and the nominal strength of the auxilia [3] follow in diminishing importance. The rest are relatively insignificant.

In revisiting the assumptions in Table 2, it is important to beware the danger of overconfidence. Some of the ranges in Table 2 may appear too wide. They are certainly wider than other estimates in circulation. But great caution should be taken in reducing them. It is well established that assessments of uncertainty tend to be biased by over-confidence - a propensity to underestimate the range of values that are possible. ${ }^{173}$ Table 2 attempts to represent the full extent of uncertainty given the current state of our knowledge. I do not see much scope to reduce the ranges without significant new information.

\footnotetext{
172 This is a 'nominal range' sensitivity analysis. On this and other forms of uncertainty analysis, see Morgan and Henrion 1990: 207-11; Vose 2008: 80-88. In the case of the single uncertain 'event', the possibility that legionaries received citizenship for any peregrine children at discharge [15], the test measures the effect of switching it from false to true.

${ }^{173}$ Edwards, Miles and von Winterfeldt 2007: 143-4; Garthwaite, Kadane and O'Hagan 2005: 685
} 
A final aspect that demands careful scrutiny is the question of interdependence, specifically epistemic interdependence. ${ }^{174}$ The Monte Carlo simulation treats most uncertain quantities as independent random variables. The method can accommodate interdependence, but only if it is acknowledged and quantified. The test for epistemic interdependence is a hypothetical question: would acquiring new information about one quantity change an historian's beliefs about the second quantity. If so, the estimates are not independent. Most of the pairs of variables in the model pass this test of independence. For example, even if we somehow discovered exact figures for the representation of citizens in the auxilia, the uncertainty about family size would remain unchanged. But there are a number of pairs that are clearly not independent, such as the representation of citizens in the auxilia and in the legions. If we were to discover that the proportion of citizen recruits to the auxiia was approaching $100 \%$ in 212 , we would be in a position to rule out significant recruitment of peregrines to the legions at that point. The interdependencies that I have taken into account are noted in Table 2 . The model accommodates them by exaggerating the interdependence and assuming a perfect linear correlation between the variables. ${ }^{175}$

\section{CONCLUSION}

The army looms large in the social history of the regions that supplied recruits or received discharged veterans in significant numbers. Studies often rely on rough assessments of the scale of recruitment and discharge. These are vulnerable to errors similar to those that have distorted estimates of the scale of enfranchisement. There is an understandable but unfortunate tendency to focus on the well-documented complement of legions at the expense of the auxiliary forces. But it has long been clear that the auxiliary forces were more numerous and we have ever better data for the auxilia in particular thanks to the proliferation of diplomas. There has also been insufficient attention to the chronological developments in the scale of recruitment and discharge, perhaps because the changes were relatively modest in the case of the more familiar legions. But the number of auxiliary recruits and especially veterans must have increased massively over the course of the first two centuries. The principal danger is over-estimating the number of veterans in the first century, when the auxilia was still growing and terms of service were long.

\footnotetext{
${ }^{174}$ On epistemic interdependence, see Garthwaite, Kadane and O'Hagan 2005: 686; Lindley 2006: 53-3.

${ }^{175}$ For the strategy adopted here, see Lavan 2016: 25; Lavan 2019a: 18-19.
} 
In the case of grants of citizenship, three key factors have led to a persistent tendency to over-estimate the scale of the phenomenon. First, scholars have tended to extrapolate from a single estimate of the number of beneficiaries at some point in the early second century, without allowing for the fact that was when the volume of grants was at a peak. Second, they have overestimated the number of offspring who benefitted with their fathers. The recent proliferation in diplomas has revealed that soldiers had significantly fewer children than expected, particularly in the first century. Third, they made no allowance for the growth in the representation of citizens among auxiliary recruits. ${ }^{176}$ Whereas past estimates have ranged from two million to as high as six million beneficiaries, the calculations in Part iii show that the actual figure is very unlikely to have exceeded a million. Even after making allowance for the fleets, the legions and grants before Claudius (all ignored by past estimates), the total number of beneficiaries should have been less than 1.6 million. There remains the question of the indirect contribution of conubium, which would have allowed veterans' rate of social reproduction as citizens to exceed their rate of biological reproduction. While I have not attempted to quantify this effect here, it is likely to have been largely or wholly offset by the depressed rate of family formation in the larger population of citizen soldiers.

There are limits to the value of an aggregate statistic. The number of enfranchised soldiers and children may have been relatively modest at the level of the empire as a whole, but still had a significant effect on specific populations. Many veterans settled in the frontier provinces where they had served. The cumulative effect on the prevalence of citizenship in those areas may have been significant. The effects could have been even more pronounced in important zones of recruitment when veterans returned home in significant numbers, as seems to have been the case with Batavians and Thracians. ${ }^{177}$ Nevertheless, the aggregate figure is important for our beliefs about the rate at which provincials became Roman citizens over the two centuries between the death of Augustus and Caracalla's universal grant of citizenship, the constitutio Antoniniana. Indeed those scholars who have envisaged a system with as many as six million direct beneficiaries suggested that this meant that the impact of Caracalla's grant must have been relatively modest. ${ }^{178}$ Even six million would be relatively

\footnotetext{
${ }^{176}$ Given the considerable uncertainty on this count, it is worth noting that this is the least important of the three factors. Even assuming (against the evidence) that no citizen was ever recruited to the auxilia, the total number of beneficiaries would still be much lower than suggested: 1.4-2.1 million.

${ }^{177}$ Batavians: Willems 1984: 234-7; Roymans 2011. Thracians: Gerov 1961; Roxan 1997: 487.

178 Webster 1998: 279; Valvo 2012: 546.
} 
small in relation to a provincial population of thirty to sixty million. But a figure of 0.9-1.6 million is clearly negligible at that level. I have argued elsewhere that scholars have tended to exaggerate the scale of enfranchisement between Augustus and Caracalla and suggested that citizens remained just 15-33 per cent of the free population of the provinces on the eve of the constitutio Antoniniana. ${ }^{179}$ This paper aims to buttress that argument by showing that the contribution of the single best-documented route to citizenship has been consistently and significantly over-estimated. ${ }^{180}$

University of St Andrews

mp12@st-andrews.ac.uk

\section{BIBLIOGRAPHY}

RMD = M. M. Roxan, then P. Holder (eds), Roman Military Diplomas I-V, London, 19782006.

RGMZ = B. Pferdehirt (ed), Römische Militärdiplome und Entlassungsurkunden in der Sammlung des Römisch-Germanischen Zentralmuseum, Mainz, 2002.

Alföldy, G. 1966: 'Notes sur la relation entre le droit de cité et la nomenclature dans l'Empire romain', Latomus 25, 37-57.

Alföldy, G. 1968a: Die Hilfstruppen der römischen Provinz Germania inferior, Düsseldorf.

Alföldy, G. 1968b: 'Zur Beurteilung der Militärdiplome der Auxiliarsoldaten', Historia 17, 215-227.

Alston, R. 1995: Soldier And Society in Roman Egypt: A Social History, London and New York.

Arnaud-Lindet, M.-P. 1977: 'Remarques sur l'octroi de la civitas et du conubium dans les diplômes militaires', Revue des études latines 55, 282-310.

Bagnall, R. S. 1993: 'Notes on Egyptian census declarations', Bulletin of the American Society of Papyrologists 30, 35-56.

Bagnall, R. S. and Frier, B. W. 1994: The Demography of Roman Egypt, Cambridge.

Bang, P. 2013: 'The Roman Empire II: the monarchy', in P. F. Bang and W. Scheidel (eds), The Oxford Handbook of the State in the Ancient Near East and Mediterranean, Oxford, 412-72.

\footnotetext{
${ }^{179}$ Lavan 2016.

${ }^{180}$ The much simpler model of grants to soldiers in Lavan 2016 (which ignored inter alia the recruitment of peregrines to the legions and citizens to the auxilia) estimated a total of 1.2-1.9 million direct beneficiaries. The more detailed model developed here shows that this over-estimated the scale of grants by c. 20 per cent, confirming that my initial analysis erred on the side of exaggerating the number of new citizens (Lavan 2016: 20).
} 
Beutler, F. 2007: 'Claudius und der Beginn der Militärdiplome - Einige Gedanken', in Speidel and Lieb 2007, 1-10.

Birley, A. R. 1981: 'The economic effects of Roman frontier policy', in A. King and M. Henig (eds), The Roman West in the Third Century, Oxford, 39-53.

Birley, E. 1938: 'Corpus Inscriptionum Latinarum, Vol. XVI: Diplomata Militaria by H. Nesselhauf, Journal of Roman Studies 28, 224-9.

Birley, E. 1986: 'Before diplomas, and the Claudian reform', in Eck and Wolff 1986, 24957.

Box, G. E. P. 1987: Empirical Model-building and Response Surfaces, New York.

Breeze, D. J. and Dobson, B. 2000: Hadrian's Wall, 4th edn. London.

Brunt, P. A. 1971: Italian Manpower, 225 B.C.-A.D. 14, Oxford.

Buck, C. E., Cavanagh, W. G. and Litton, C. 1996: Bayesian Approach to Interpreting Archaeological Data, Chichester.

Callies, H. 1964: 'Die fremden Truppen im römischen Heer des Prinzipats und die sogenannten nationalen Numeri', Beiträge zur Geschichte des römischen Heeres 45, 130227.

Cheesman, G. L. 1914: The Auxilia of the Roman Imperial Army, Oxford.

Dana, D. 2013: 'Conubium cum uxoribus: mariages thraces dans les diplômes militaires', Cabiers du Centre Gustave-Glotz 24, 217-40.

De Finetti, B. 1989: 'Probabilism: a critical essay on the theory of probability and on the value of science', Erkenntnis 31.2/3, 169-223.

Dietze-Mager, G. 2007: 'Der Erweb der Römischen Bürgerrechts in Ägypten. Legionare und Veteranen', Journal of Juristic Papyrology 37, 91-105.

Dušanić, S. 1982: 'The issue of military diplomata under Claudius and Nero', Zeitschrift für Papyrologie und Epigraphik 47, 149-71.

Dušanić, S. 1986: 'Pre-Severan diplomata and the problem of "special” grants', in Eck and Wolff 1986, 190-240.

Eck, W. 2003: 'Der Kaiser als Herr des Heeres. Militärdiplome und kaiserliche Reichsregierung', in J. J. Wilkes (ed), Documenting the Roman Army, London, 55-.

Eck, W. 2007a: 'Die Veränderungen in Konstitutionen und Diplomen unter Antoninus Pius', in M. P. Speidel and H. Lieb (eds), Militärdiplome: Die Forschungsbeiträge der Berner Gespräche von 2004. Mavors: Roman army researches 15. Stuttgart, 87-104.

Eck, W. 2007b: Rom herausfordern: Bar Kochba im Kampf gegen das Imperium Romanum. Das Bild des Bar Kochba-Aufstandes im Spiegel der neuen epigraphischen Uberlieferung, Rome.

Eck, W. 2010: 'Recht und Politik in den Bürgerrechtskonstitutionen der römischen Kaiserzeit', Scripta Classica Israelica 29,

Eck, W. 2012a: Bürokratie und Politik in der römischen Kaiserzeit: Administrative Routine und politische Reflexe in Bürgerrechtskonstitutionen der römischen Kaiser, Wiesbaden.

Eck, W. 2012b: 'Diplomata militaria für Prätorianer vor und seit Septimius Severus. Eine Bestandsaufnahme und ein Erklärungsversuch', Athenaeum 100, 321-36.

Eck, W. 2012c: 'Friedenssicherung und Krieg in der Römischen Kaiserzeit: Wie ergänzt man das römische Heer?', in A. Eich (ed), Die Verwaltung der kaiseržeitlichen römischen Armee. Studien für Hartmut Wolff, Stuttgart, 87-110.

Eck, W. 2013: 'Die kaiserliche Bürgerrechtspolitik im Spiegel der Militärdiplome - ein Thema Hartmut Wolffs', Passauer Jabrbuch 55, 9-24.

Eck, W. 2016: 'Die Entwicklung der Auxiliareinheiten als Teil des römischen Heeres in der frühen und hohen Kaiserzeit, ' in C. Wolff and P. Faure (eds), Les auxiliaires de 
l'armée romaine. Des alliés aux fédérés. Actes du sixième Congrès de Lyon - 23 - 25 octobre 2014, Lyons, 111-126.

Eck, W. 2017: 'Geschriebene Kommunikation: 200 Jahre kaiserliche Politik im Spiegel der Bürgerrechtskonstitutionen', in M. Bellomo and S. Segenni (eds), Epigrafia e politica. Il contributo della documentazione epigrafica allo studio delle dinamiche politiche nel mondo romano, Milan, 7-26.

Eck, W., MacDonald, D. and Pangerl, A. 2003: 'Die Krise des römischen Reiches unter Marc Aurel und ein Militärdiplom aus dem Jahr 177 (?)', Chiron 33, 365-77.

Eck, W. and Pangerl, A. 2003: 'Vater, Mutter, Schwestern, Brüder', Chiron 33, 347-64.

Eck, W. and Pangerl, A. 2008: 'Moesia und seine Truppen. Neue Diplome für Moesia superior', Chiron 38, 317-87.

Eck, W. and Pangerl, A. 2015: 'Eine zweite Kopie der Konstitution für die Truppen Syriens vom 19. März 144 und ein Diplom für die equites singulares vom selben Datum', Zeitschrift für Papyrologie und Epigraphik 193, 253-60.

Eck, W. and Pangerl, A. 2016: 'Ein Diplom mit der Sonderformel praeterea praestitit', Zeitschrift für Papyrologie und Epigraphik 198, 239-44.

Eck, W., Pangerl, A. and Weiss, P. 2014: 'Edikt Hadrians für Praetorianer mit unsicherem Römischen Bürgerrecht', Zeitschrift für Papyrologie und Epigraphik 189, 241-53.

Eck, W. and Wolff, H. (eds) 1986: Heer und Integrationspolitik: Die römischen Militardiplome als bistorische Quelle, Cologne.

Edwards, W., Miles, R. F., Jr. and von Winterfeldt, D. 2007: Advances in Decision Analysis: From Foundations to Applications, Cambridge and New York.

Forni, G. 1953: Il reclutamento delle legioni da Augusto a Diocleziano, Rome.

Forni, G. 1968: 'Sull'ordinamento ed impiego della flotta di Ravenna', in Atti del convegno internazionale di studi d'antichita di Classe (14-17 ottobre 1967), Ravenna, 265-81.

Forni, G. 1974: 'Estrazione etnica e sociale dei soldati delle legioni nei primi tre secoli dell'impero', Aufstieg und Niedergang der römischen Welt II 1, 339-91.

Frier, B. W. 1982: 'Roman life expectancy: Ulpian's evidence', Harvard Studies in Classical Philology 86, 213-51.

Frier, B. W. 2000: 'Demography', in A. K. Bowman, P. Garnsey and D. Rathbone (eds), The Cambridge Ancient History. Volume 11: The High Empire, AD 70-192, 2nd edn. Cambridge, 787-816.

Gallet, S. and Le Bohec, Y. 2007: 'Le recrutement des auxiliaries d' après les diplomes militaires et les autres inscriptions', in Speidel and Lieb 2007, 267-92.

Garthwaite, P. H., Kadane, J. B. and O'Hagan, A. 2005: 'Statistical methods for eliciting probability distributions', Journal of the American Statistical Association 100(470), 680700.

Gerov, B. 1961: 'Burgerrechtsverleihung und Kolonisation in Thrakien vor Trajan', Studii clasice 3, 107-116.

Gilliam, J. F. 1965: 'Dura rosters and the "Constitutio Antoniniana”, Historia 14, 74-92.

Greenberg, J. 2003: 'Plagued by doubt: reconsidering the impact of a mortality crisis in the 2nd c. A.D.', Journal of Roman Archaeology 16, 413-25.

Greene, E. M. 2015: 'Conubium cum uxoribus: Wives and children in the Roman military diplomas', Journal of Roman Archaeology 28, 125-59.

Grosso, F. 1966: 'Equites singulares Augusti', Latomus 25, 900-9.

Hassall, M. 1983: 'The internal planning of Roman auxiliary forts', in B. Hartley and J. Wacher (eds), Rome and her Northern Provinces, Gloucester, 96-131. 
Haynes, I. 2001: 'The impact of auxiliary recruitment on provincial societies from Augustus to Caracalla', in L. De Blois (ed), Administration, Prosopography and Appointment Policies in the Roman Empire. Proceedings of the First Workshop of the International Network Impact of Empire (Roman Empire, 27 B.C. - A.D. 406), Leiden, June 28-July 1, 2000, Amsterdam, 62-83.

Haynes, I. 2013: Blood of the Provinces: The Roman Auxilia and the Making of Provincial Society from Augustus to the Severans, Oxford.

Holder, P. A. 1980: The Auxilia from Augustus to Trajan, BAR International Series 70, Oxford.

Holder, P. A. 2003: ‘Auxiliary deployment in the reign of Hadrian', in J. J. Wilkes (ed), Documenting the Roman army. Essays in honour of Margaret Roxan, London, 101-45.

Holder, P. A. 2006: 'Auxiliary deployment in the reign of Trajan', Dacia NS 50, 141-74.

Holder, P. A. 2007: 'Observations on auxiliary diplomas from Vespasian to Commodus', in Speidel and Lieb 2007, 105-63.

Jacques, F. and Scheid, J. 1990: Rome et l'integration de l'Empire (44 av. J.-C.-260 ap. J.-C.). Tome 1, Les structures de l'empire romain, Paris.

Jung, J. H. 1982: 'Das Eherecht der römischen Soldaten', Aufstieg und Niedergang der römischen Welt II.14, 302-46.

Juntunen, K. 2018: 'The marital patterns of the Roman auxiliary soldiers in the diplomata militaria', in C. S. Sommer and S. Matesic (eds), Limes XXIII. Proceedings of the 23. International Congress of Roman Frontier Studies Ingolstadt 2015, Mainz, 1039-45

Kaplan, S. 1993: 'Formalisms for handling phenomenological uncertainties: the concepts of probability, frequency, variability, and probability of frequency', Nuclear Technology 102.1, 137-42.

Kaser, M. 1955-9: Das römische Privatrecht, Munich.

Kienast, D. 1966: Untersuchungen zu den Kriegsflotten der römischen Kaiserzeit, Bonn.

Kraft, K. 1951: Zur Rekrutierung der Alen und Kohorten an Rhein und Donau, Bern.

Lavan, M. 2016: 'The spread of Roman citizenship, 14-212 CE: Quantification in the face of high uncertainty', Past and Present 230, 3-46.

Lavan, M. 2019a: 'Epistemic uncertainty, subjective probability and ancient history', Journal of Interdisciplinary History 50.1, 1-21.

Lavan, M. 2019b: 'The manpower of the Roman fleets', Journal of Roman Archaeology 31, forthcoming.

Lavan, M. forthcoming: 'Roman citizenship, marriage with non-citizens and family networks', in C. Ando and M. Lavan (eds), Imperial and Local Citizenships in the Long Second Century CE.

Le Bohec, Y. 1989: L'Armée romaine sous le Haut-Empire, Paris.

Le Roux, P. 1986: 'Des diplômes militaires et l'évolution de l'armée romaine de Claude à Septime Sévère: auxilia, numeri et nationes', in Eck and Wolff 1986, 347-374.

Lesquier, J. 1918: L'armée romaine d'Égypte d'Auguste à Dioclétien, Cairo.

Lindley, D. V. 2006: Understanding Uncertainty, Hoboken.

Link, S. 1989: Konzepte der Privilegierung römischer Veteranen, Habes 9, Stuttgart.

MacMullen, R. 1980: 'How big was the Roman imperial army?', Klio 62, 451-60.

Mann, J. C. 1954: 'A note on the numeri', Hermes 82, 501-6.

Mann, J. C. 1983: Legionary Recruitment and Veteran Settlement during the Principate, Institute of Archaeology Publications 7, London. 
Mann, J. C. 2000: 'Honesta missio', in G. Alföldy (ed), Kaiser, Heer und Gesellschaft in der römischen Kaiserzeit. 153-.

Mann, J. C. 2002: 'Name forms of recipients of diplomas', Zeitschrift für Papyrologie und Epigraphik 139, 227-34.

Marotta, V. 2009: La cittadinanza romana in età imperiale (secoli I-III d.C.), Turin.

Marotta, V. 2014: 'Egizi e cittadinanza romana', Cultura giuridica e diritto vivente 1, 1-21.

Maxfield, V. A. 1981: The Military Decorations of the Roman Army, Berkeley and Los Angeles.

Mirković, M. 2004: 'The roster of the VII Claudia Legion', Zeitschrift für Papyrologie und Epigraphik 146, 211-20.

Mócsy, A. 1986: 'Die Namen der Diplomempfänger', in Eck and Wolff 1986, 437-66.

Mommsen, T. 1881: 'Schweizer Nachstudien', Hermes 16.3: 445-494 (=Gesammelte Schriften II, 1908, 390-437).

Morgan, M. G. and M. Henrion 1990: Uncertainty: A Guide to Dealing with Uncertainty in Quantitative Risk and Policy Analysis, Cambridge.

Nesselhauf, H. (ed) 1936: Corpus Inscriptionum Latinarum XVI: Diplomata Militaria. Berlin.

O'Hagan, A., Buck, C. E., Daneshkah, A., Eiser, J. R. , Garthwaite, P. H., Jenkinson, D. J., Oakley, J. E. and Rakow, T. 2006: Uncertain judgements: Eliciting experts' probabilities, Chichester.

Pearce, J. and Tomlin, R. S. O. 2018: 'A Roman military diploma for the German fleet (19 November 150) found in northern Britain', Zeitschrift für Papyrologie und Epigraphik 206, 207-16.

Pferdehirt, B. 2002: Die Rolle des Militärs für den sozialen Aufstieg in der römischen Kaiserzeit, Mainz.

Phang, S. E. 2001: The Marriage of Roman Soldiers (13 BC-AD 235): Law and Family in the Imperial Army, Leiden.

Raepsaet-Charlier, M.-T. 2001: 'Onomastique et romanisation: éléments d'une comparaison entre les provinces de Gaule Belgique et de Germanie inférieure', in M. Dondin-Payre and M.-T. Raepsaet-Charlier (eds), Noms, identités culturelles et romanisation sous le Haut-Empire, Brussels, 399-470.

Rankov, B. 2007: 'Roman military forces', in P. Sabin, H. Van Wees and M. Whitby (eds), The Cambridge history of Greek and Roman warfare: Volume 1, Greece, The Hellenistic World and the rise of Rome, Cambridge, 30-75.

Rathbone, D. 2001: 'PSI XI 1183: Record of a Roman census declaration of A.D. 47/8', in T. Gagos and R. S. Bagnall (eds), Essay and Texts in Honor of J. David Thomas, Oakville, 99-113.

Reddé, M. 1986: Mare nostrum: les infrastructures, le dispositif et l'bistoire de la marine militaire sous l'empire romain, Rome.

Reuter, M. 1999: 'Studien zu den numeri des römischen Heeres in der mittleren Kaiserzeit', Bericht der Römisch-Germanischen Kommission 80, 359-569.

Rocco, M. 2010: 'The reasons behind the Constitutio Antoniniana and its effects on the Roman military', Acta Classica Universitatis Scientiarum Debreceniensis 46, 131-56.

Roth, J. 1994: 'The size and organization of the Roman imperial legion', Historia 43.3, 346-62.

Rowell, H. T. 1939: 'The honesta missio from the numeri of the Roman Imperial Army', Yale Classical Studies 6, 73-108.

Roxan, M. M. 1986: 'Observations on the reasons for changes in formula in diplomas circa AD 140', in Eck and Wolff 1986, 265-92. 
Roxan, M. M. 1989: 'Findspots of military diplomas of the Roman auxiliary army', Institute of Archaeology Bulletin 26, 127-81.

Roxan, M. M. 1994: Roman Military Diplomas 1985-1993, London.

Roxan, M. M. 1997: 'Settlement of the veterans of the auxilia: a preliminary study', in W. Groenman-van Waateringe, B. van Beek, W. Willems and S. Wynia (eds), Roman Frontier Studies 1995. Proceedings of the 16th International Congress of Roman Frontier Studies, Oxford, 483-92.

Roxan, M. M. and Holder, P. 2003: Roman Military Diplomas IV, London.

Roymans, N. 2011: 'Ethnic recruitment, returning veterans and the diffusion of Roman culture among rural populations in the Rhineland frontier zone', in N. Roymans and T. Derks (eds), Villa Landscapes in the Roman North: Economy, Culture, and Lifestyles, Amsterdam, 139-60.

Sablayrolles, R. 1996: Libertinus miles. Les cohortes de vigiles, Rome.

Saddington, D. B. 1975: 'The development of the Roman auxiliary forces from Augustus to Trajan', Aufstieg und Niedergang der römischen Welt II.3, 176-201.

Saddington, D. B. 2007: 'Classes. The evolution of the Roman imperial fleets', in P. Erdkamp (ed), A Companion to the Roman Army, Malden and Oxford, 201-17.

Saller, R. P. 1994: Patriarchy, Property and Death in the Roman Family, Cambridge.

Salomies, O. 1996: 'Observations on Some Names of Sailors Serving in the Fleets at Misenum and Ravenna', Arctos 30, 167-86.

Scheidel, W. 1996: Measuring Sex, Age And Death in The Roman Empire: Explorations in Ancient Demography, Journal of Roman Archaeology Supplementary Series 21, Ann Arbor.

Scheidel, W. 2007: 'Marriage, families and survival: Demographic aspects', in P. Erdkamp (ed), Companion to the Roman army. 417-34.

Southern, P. 1989: 'The numeri of the Roman imperial army', Britannia 20, 81-140.

Spaul, J. 2000: Cohors², BAR International Series 841, Oxford.

Speidel, M. A. 2013: 'Les femmes et la bureaucratie. Quelques réflexions sur l'interdiction du mariage dans l'armée romaine', Cabiers du Centre Gustave-Glotz,24, 205-15.

Speidel, M. A. 2015: 'Kaiserliche Privilegien, Urkunden und die "Militäranarchie” des Zeitalters der "Soldatenkaiser". Einige Beobachtungen', in U. Babusiaux and A. Kolb (eds), Das Recht der 'Soldatenkaiser'. Rechtliche Stabilität in Zeiten politischen Umbruchs?, Berlin, 46-64.

Speidel, M. A. and Lieb, H. (eds) 2007: Militärdiplome: Die Forschungsbeiträge der Berner Gespräche von 2004, Mavors: Roman army researches 15, Stuttgart.

Speidel, M. P. 1965: Die Equites Singulares Augusti. Begleittruppe der römischen Kaiser des zweiten und dritten Jabrhunderts, Bonn.

Spiegelhalter, D. 2011: 'Quantifying uncertainty', in L. Skinns, M. Scott and T. Cox (eds), Risk (Darwin College Lectures), Cambridge, 17-33.

Starr, C. G. 1941: The Roman Imperial Navy 31 B.C. - A.D. 32, Ithaca.

Stylow, A. U. 1994: 'Ein neues Militärdiplom von 133. Zum personenrechtlichen Status der equites singulares Augusti', Chiron 24, 83-94.

Terreni, C. 1999: 'Gaio e l'erroris causae probatio', Labeo 45.3, 333-367.

Thomas, C. 2004: 'Claudius and the Roman army reforms', Historia 53, 424-452.

Treggiari, S. 1991: Roman Marriage: Iusti Coninges from the Time of Cicero to the time of Ulpian, Oxford. 
Valvo, A. 2003: 'Veterani ex legionibus instrumentum accipere non solent', Athenaeum 91, 173-184.

Valvo, A. 2012: 'I diplomi militari e la constitutio antoniniana', in A. Donati and G. Poma (eds), L'officina epigrafica romana. In ricordo di Giancarlo Susini, Faenza, 533-46.

Visy, Z. 1995: 'Bemerkungen zur Frage der Lange des Militärdienstes aufgrund Militardiplome', Specimina Nova 11, 223-30.

Vittinghoff, F. 1950: 'Zur angeblichen Barbarisierung des römischen Heeres durch die Verbände der Numeri', Historia 1, 389-407.

Vittinghoff, F. 1952: Römische Kolonisation und Bürgerrechtspolitik unter Caesar und Augustus, Wiesbaden.

Vittinghoff, F. 1986, 'Militärdiplome, römische Bürgerrechts- und Integrationspolitik der Hohen Kaiserzeit', in Eck and Wolff 1986, 535-55 (=Civitas Romana. 1994, 28298).

Vose, D. 2008: Risk Analysis: A Quantitative Guide, Chichester.

Waebens, S. 2012a: 'Imperial policy and changed composition of the auxilia: The "change in A.D. 140" revisited', Chiron 42, 1-23.

Waebens, S. 2012b: 'The legal status of legionary recruits in the Principate: a case study (Lucius Pompeius Niger, A.D. 31-64)', in C. Wolff (ed), Le métier de soldat dans le monde romain, Paris, 235-253.

Waebens, S. 2012c: 'Reflecting the "change in A.D. 140": the veteran categories of the epikrisis documents revisited', Zeitschrift für Papyrologie und Epigraphik 180, 267-77.

Webster, G. 1998: The Roman Imperial Army of the First and Second Centuries AD, 3rd edn. Norman.

Weiss, P. 2008: 'Die vorbildliche Kaiserehe. Zwei Senatsbeschlüsse beim Tod der älteren und der jüngeren Faustina, neue Paradigmen und die Herausbildung des “antoninischen” Prinzipats', Chiron 38, 1-45.

Weiss, P. 2017: 'Die Militärdiplome unter Marc Aurel und Commodus: Kontinuitäten und Brüche', in V. Grieb and K. C. (eds), Marc Aurel - Wege zu seiner Herrschaft, Gutenberg, 135-53.

Wesch-Klein, G. 2007: 'Recruits and veterans', in P. Erdkamp (ed), Companion to the Roman Army, Malden and Oxford, 435-50.

Wilkes, J. J. 2002: 'The legions in the principate: updating Ritterling', Journal of Roman Archaeology 15, 528-35.

Willems, W. J. H. 1984: 'Romans and Batavians. A Regional Study in the Dutch Eastern River Area II', Berichten van de Rijksdienst voor het Oudheidkundig Bodemonderzoek 34, 39-331.

Wolff, H. 1974: 'Zu den Bürgerrechtsverleihungen an Kinder von Auxiliaren und Legionaren', Chiron 4, 479-510.

Wolff, H. 1976: Die Constitutio Antoniniana und Papyrus Gissensis 40 I, 2 vols. Cologne.

Wolff, H. 2007: 'Die römische Bürgerrechtspolitik nach den Militärdiplomen', in Speidel and Lieb 2007, 345-72.

Woods, R. 2007: 'Ancient and early modern mortality: experience and understanding', The Economic History Review 60, 373-99. 
Table 1

\section{ACTUAL/NOMINAL STRENGTH}

\begin{tabular}{|c|c|c|c|c|c|}
\hline Unit and date & Unit type & $\begin{array}{l}\text { Nominal } \\
\text { strength }^{\mathrm{a}}\end{array}$ & $\begin{array}{l}\text { Actual } \\
\text { strength }\end{array}$ & $\begin{array}{l}\text { Actual/ } \\
\text { nominal } \\
\text { strength }\end{array}$ & Source \\
\hline $\begin{array}{l}\text { cohors XX } \\
\text { Palmyrenorum, c. } \\
219^{\mathrm{b}}\end{array}$ & c. mill. equit. & 1056 & $\sim 1210$ & $115 \%$ & $\begin{array}{l}\text { Rom. Mil.Rec } 1 \text { = P Dura } 100 \text { with } \\
\text { Fink at } P . \text { Dura p. } 31\end{array}$ \\
\hline $\begin{array}{l}\text { cohors XX } \\
\text { Palmyrenorum, c. } 222\end{array}$ & c. mill. equit. & $1056^{\mathrm{b}}$ & $\sim 1040$ & $98 \%$ & $\begin{array}{l}\text { Rom.Mil.Rec } 2=P \text { Dura } 101 \text { with } \\
\text { Fink at } P . \text { Dura p. } 31\end{array}$ \\
\hline $\begin{array}{l}\text { cohors I Tungrorum, } \\
\text { ca } 90\end{array}$ & c. mill. & 800 & 746 & $93 \%$ & $\begin{array}{l}T \text { Vindol. } 154 \text { (total for } 18 \text { May, less } \\
6 \text { officers but including absent and } \\
\text { incapacitated) }\end{array}$ \\
\hline $\begin{array}{l}\text { cohors V Vigilum, } \\
210\end{array}$ & & $1120 ?^{\mathrm{c}}$ & $\sim 1027$ & $92 \%$ & CIL vi 1058 with Rainbird 1986150 \\
\hline $\begin{array}{l}\text { cohors I Hispanorum } \\
\text { veterana, } 105-8\end{array}$ & $\begin{array}{l}\text { c. quin. } \\
\text { equit. }\end{array}$ & 608 & 536 & $88 \%$ & $\begin{array}{l}\text { Rom.Mil.Rec } 63 \text { (total for Sept. } 16 \\
\text { less } 10 \text { officers) }\end{array}$ \\
\hline $\begin{array}{l}\text { ala Commagenorum, } \\
48-51\end{array}$ & a. quin. & 512 & 434 & $85 \%$ & $\begin{array}{l}\text { Ch.L.A. XI } 501 \text { (complement of } \\
\text { equites on } 28 \text { May). The reading } \\
\text { [c]cccxxiv is convincing, but a figure } \\
\text { of } 334 \text { (implying a ratio of just } 65 \% \text { ) } \\
\text { cannot be ruled out entirely. }\end{array}$ \\
\hline $\begin{array}{l}\text { cohors I Augusta } \\
\text { Praetoria } \\
\text { Lusitanorum, } 156\end{array}$ & $\begin{array}{l}\text { c. quin. } \\
\text { equit. }\end{array}$ & 608 & 496 & $82 \%$ & $\begin{array}{l}\text { Rom.Mil.Rec } 64 \text { (strength on } \\
\text { January } 1 \text { less } 9 \text { officers) }\end{array}$ \\
\hline $\begin{array}{l}\text { unknown cohors } \\
\text { equitata, ca } 215\end{array}$ & $\begin{array}{l}\text { c. quin. } \\
\text { equit. }\end{array}$ & 608 & 447 & $74 \%$ & $\begin{array}{l}\text { Thomas and Davies } 1977 \text { (reliqui } \\
\text { less } 10 \text { officers) }\end{array}$ \\
\hline Average $^{d}$ & & & & $89 \%$ & \\
\hline
\end{tabular}

Notes: (a) Nominal strengths (excluding centurions and decurions) for auxiliary units as per Holder 2003 120, as in my assumption for the total nominal strength of the auxilia. (b) There is no independent evidence for whether this cohort was milliary or quingenary. It was clearly over-strength, perhaps massively so, probably as a response to an eastern threat. Rather than discount it entirely, I assume it was nominally milliary. (c) Rainbird's hypothesis. The resulting ratio is very close to the average, so it seems plausible. (d) Counts cohors XX Palmyrenorum once, at the average of the two reported strengths. 


\section{VARIABLES AND ASSUMPTIONS}

\begin{tabular}{|c|c|c|c|c|c|c|c|c|c|}
\hline & No.* & Variable/assumption & & Min. & $\begin{array}{l}\text { Most } \\
\text { likely }\end{array}$ & Max. & 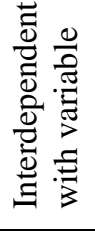 & 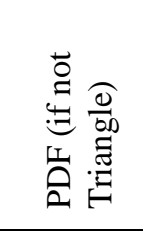 & 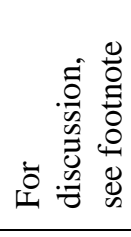 \\
\hline & [1] & Actual/nominal strength & & $81 \%$ & $89 \%$ & $96 \%$ & & & 129 \\
\hline 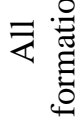 & {$[2]$} & 25-year attrition rate & & $40 \%$ & $50 \%$ & $60 \%$ & & & 136 \\
\hline \multirow{19}{*}{ 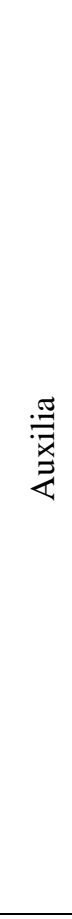 } & \multirow[t]{6}{*}[3]{} & Nominal strength & 14 & 110 & 150 & 160 & & & 124 \\
\hline & & \multirow{5}{*}{ ('000s) } & 69 & 140 & 180 & 190 & & & 123 \\
\hline & & & 99 & 193 & 214 & 229 & & & 122 \\
\hline & & & 128 & 200 & 222 & 240 & & & 119 \\
\hline & & & 161 & 200 & 222 & 240 & & & 121 \\
\hline & & & 212 & 190 & 222 & 250 & & & “ \\
\hline & \multirow[t]{3}{*}[4]{} & \multirow{3}{*}{$\begin{array}{l}\text { Representation of citizens } \\
\text { among recruits }\end{array}$} & 15 & $7 \%$ & & $11 \%$ & $\mathrm{U}$ & {$[14]$} & 82 \\
\hline & & & 140 & $20 \%$ & & $50 \%$ & “ & “ & “ \\
\hline & & & 212 & $45 \%$ & & $80 \%$ & “ & “ & “ \\
\hline & \multirow[t]{4}{*}[5]{} & \multirow[t]{4}{*}{ Term of service } & 15 & 30 & 35 & 40 & & & 22 \\
\hline & & & 50 & 25 & 27 & 30 & & & “ \\
\hline & & & 110 & - & 25 & - & & & “ \\
\hline & & & 212 & - & 25 & - & & & “ \\
\hline & [a] & Timing of grant & & \multicolumn{3}{|c|}{ After 25 years } & & & “ \\
\hline & \multirow[t]{4}{*}[6]{} & \multirow[t]{4}{*}{ Children/beneficiary } & $14-95$ & 0.04 & 0.26 & 0.48 & & {$[10],[11]$} & 146 \\
\hline & & & $96-116$ & \multicolumn{3}{|c|}{ Linear growth to value in 117} & & “ & “ \\
\hline & & & $117-140$ & 1.6 & 2.0 & 2.5 & & “ & “ \\
\hline & & & $140-212$ & & 0 & & & & “ \\
\hline & [7] & $\begin{array}{l}\text { Scale of grants before } \\
\text { Claudius }\end{array}$ & & $10 \%$ & $20 \%$ & $90 \%$ & & & 16 \\
\hline \multirow{13}{*}{$\frac{\ddot{d}}{\frac{0}{I}}$} & {$[8]$} & Nominal strength ('000s) & & 15 & 25 & 50 & & & 126 \\
\hline & {$[\mathrm{b}]$} & $\%$ in the Italian fleets & & & $50 \%$ & & & & “ \\
\hline & [c] & Representation of citizens & 15 & & $0 \%$ & & & & 82 \\
\hline & & among recruits & 212 & & $0 \%$ & & & & \\
\hline & {$[\mathrm{d}]$} & Term of service & & & 26 & & & & “ \\
\hline & {$[\mathrm{e}]$} & Timing of grant & & & er 26 y & & & & 30 \\
\hline & [9] & Proportion of soldiers in & & $2 \%$ & $8 \%$ & $33 \%$ & & & 47 \\
\hline & & $\begin{array}{l}\text { provincial fleets who } \\
\text { continued to receive } \\
\text { citizenship for their } \\
\text { children after } 140\end{array}$ & & & & & & & \\
\hline & \multirow[t]{3}{*}[10]{} & $\begin{array}{l}\text { Children/beneficiary } \\
\text { (Italian fleets) }\end{array}$ & $15-95$ & 0.04 & 0.26 & 0.48 & & {$[6],[11]$} & 148 \\
\hline & & & $96-116$ & \multicolumn{3}{|c|}{ Linear growth to value in 117} & & & “ \\
\hline & & & $117-212$ & 0.42 & 0.79 & 1.2 & & & “" \\
\hline & \multirow[t]{2}{*}[11]{} & $\begin{array}{l}\text { Children/beneficiary } \\
\text { (provincial fleets) }\end{array}$ & $15-95$ & 0.04 & 0.26 & 0.48 & & {$[6],[10]$} & 149 \\
\hline & & & $96-116$ & \multicolumn{3}{|c|}{ Linear growth to value in 117} & & & “ \\
\hline
\end{tabular}




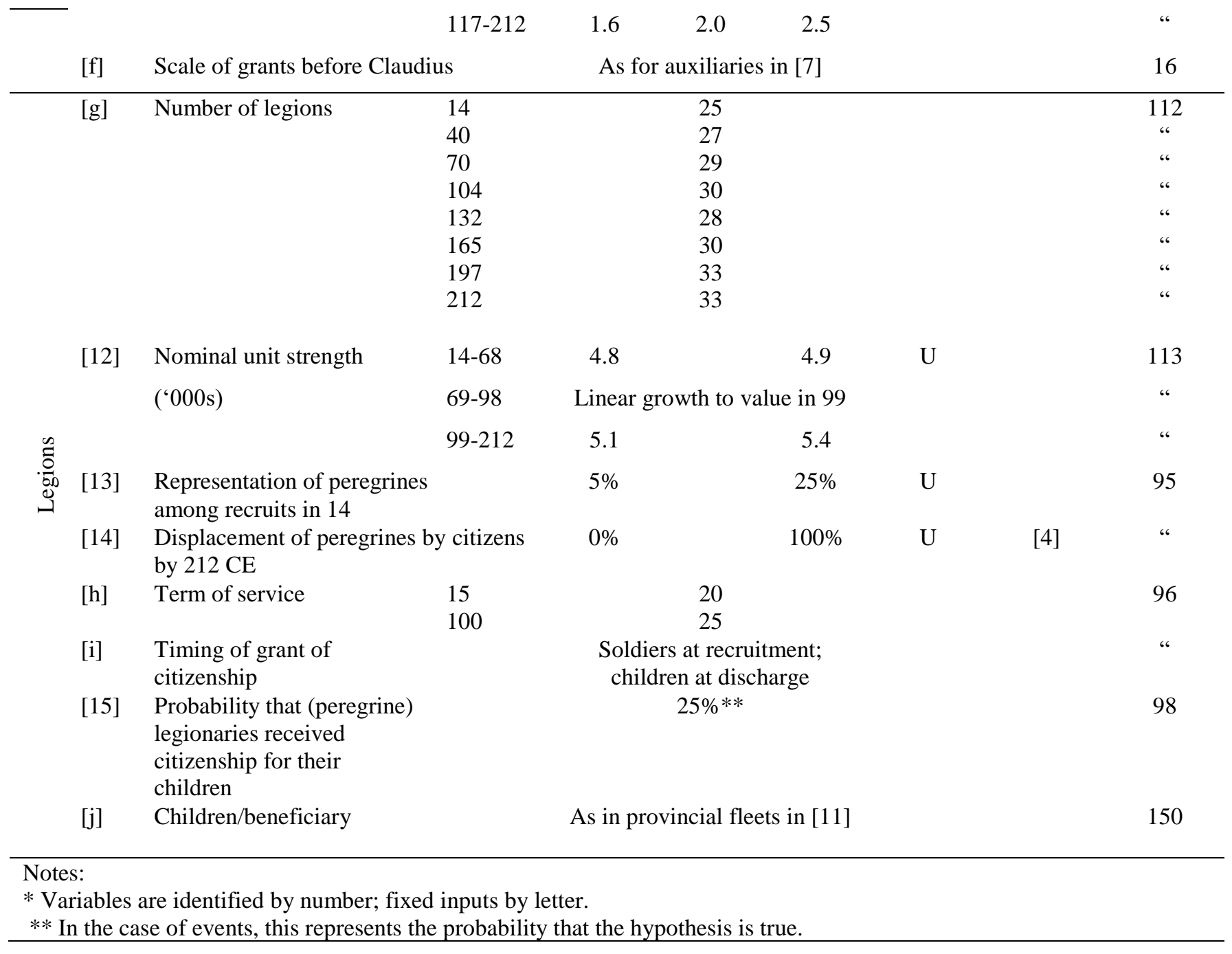




\section{Table 3}

\section{ANNUAL FLOWS IN SELECTED YEARS}

Expected value (95\% credible interval)

('000s)

\begin{tabular}{|c|c|c|c|c|c|c|}
\hline & & \multicolumn{5}{|c|}{ Situation in year } \\
\hline & & 15 & 50 & 100 & 139 & 212 \\
\hline \multirow{7}{*}{ : } & a) Recruits & $\begin{array}{c}5.9 \\
(49-69)\end{array}$ & $\begin{array}{c}7.5 \\
(63-87)\end{array}$ & $\begin{array}{c}9.6 \\
(8-108)\end{array}$ & $\begin{array}{c}10.3 \\
(02-115)\end{array}$ & $\begin{array}{c}10.3 \\
(0-119)\end{array}$ \\
\hline & b) Discharged veterans & 1.8 & 2.7 & 4.1 & 5.2 & 5.2 \\
\hline & & $(0.9-2.6)$ & $(2.1-3.4)$ & $(3.1-5)$ & $(4.4-5.9)$ & $(4.4-6)$ \\
\hline & c) Enfranchised soldiers & $\begin{array}{c}1.3 \\
(0.3)\end{array}$ & $\begin{array}{l}2.7 \\
(25)\end{array}$ & $\begin{array}{l}3.4 \\
(28-4)\end{array}$ & $\begin{array}{l}3.4 \\
(2.44)\end{array}$ & $\begin{array}{c}2.3 \\
(1.4-33\end{array}$ \\
\hline & d) Enfranchised children & 0.3 & 0.7 & 2.1 & 6.9 & $\begin{array}{c}(1.4-5.5) \\
0\end{array}$ \\
\hline & & $(0.1-0.8)$ & $(0.2-1.2)$ & $(1.3-3)$ & $(4.8-9.4)$ & $(0-0)$ \\
\hline & e) Total enfranchisements & $\begin{array}{c}1.7 \\
(0.6-2.9) \\
\end{array}$ & $\begin{array}{c}3.4 \\
(2.6-4.2) \\
\end{array}$ & $\begin{array}{c}5.5 \\
(4.2-7) \\
\end{array}$ & $\begin{array}{c}10.3 \\
(7.4-13.7)\end{array}$ & $\begin{array}{c}2.3 \\
(1.4-3.3)\end{array}$ \\
\hline \multirow{3}{*}{$\frac{\tilde{U}}{\frac{\tilde{d}}{I}}$} & f) Recruits & ------------- & -------------- & 1.4 & -------------- & -------------- \\
\hline & $\begin{array}{l}\text { g) Discharged veterans } \\
\text { (= enfranchised soldiers) }\end{array}$ & ------------- & ------------ & $\begin{array}{c}0.7 \\
(0.4-1)\end{array}$ & ------------ & ------------ \\
\hline & h) Total enfranchisements & $\begin{array}{c}0.4 \\
(0.1-0.8)\end{array}$ & $\begin{array}{c}0.8 \\
(0.5-1.3)\end{array}$ & $\begin{array}{c}1.0 \\
(0.6-1.5)\end{array}$ & $\begin{array}{c}1.5 \\
(0.9-2.4)\end{array}$ & $\begin{array}{c}0.9 \\
(0.5-1.5)\end{array}$ \\
\hline \multirow{3}{*}{ 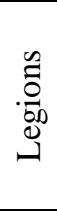 } & i) Recruits & $\begin{array}{c}6.7 \\
(6.1-7.2)\end{array}$ & $\begin{array}{c}7.2 \\
(6.6-7.8)\end{array}$ & $\begin{array}{c}7.1 \\
(6.5-7.8)\end{array}$ & $\begin{array}{c}6.9 \\
(6.3-7.5)\end{array}$ & $\begin{array}{c}8.1 \\
(7.4-8.8)\end{array}$ \\
\hline & $\begin{array}{l}\text { j) Of whom enfranchised } \\
\text { peregrines }\end{array}$ & $\begin{array}{c}0.9 \\
(0.1-1.6)\end{array}$ & $\begin{array}{c}0.8 \\
(0.1-1.6)\end{array}$ & $\begin{array}{c}0.7 \\
(0.1-1.5)\end{array}$ & $\begin{array}{c}0.6 \\
(0.1-1.4)\end{array}$ & $\begin{array}{c}0.5 \\
(0-1.6)\end{array}$ \\
\hline & k) Discharged veterans & $\begin{array}{c}4.0 \\
(3.6-4.4)\end{array}$ & $\begin{array}{c}4.0 \\
(3.6-4.4)\end{array}$ & $\begin{array}{c}4.1 \\
(3.5-4.7)\end{array}$ & $\begin{array}{c}3.7 \\
(3.2-4.2)\end{array}$ & $\begin{array}{c}3.7 \\
(3.2-4.2)\end{array}$ \\
\hline
\end{tabular}




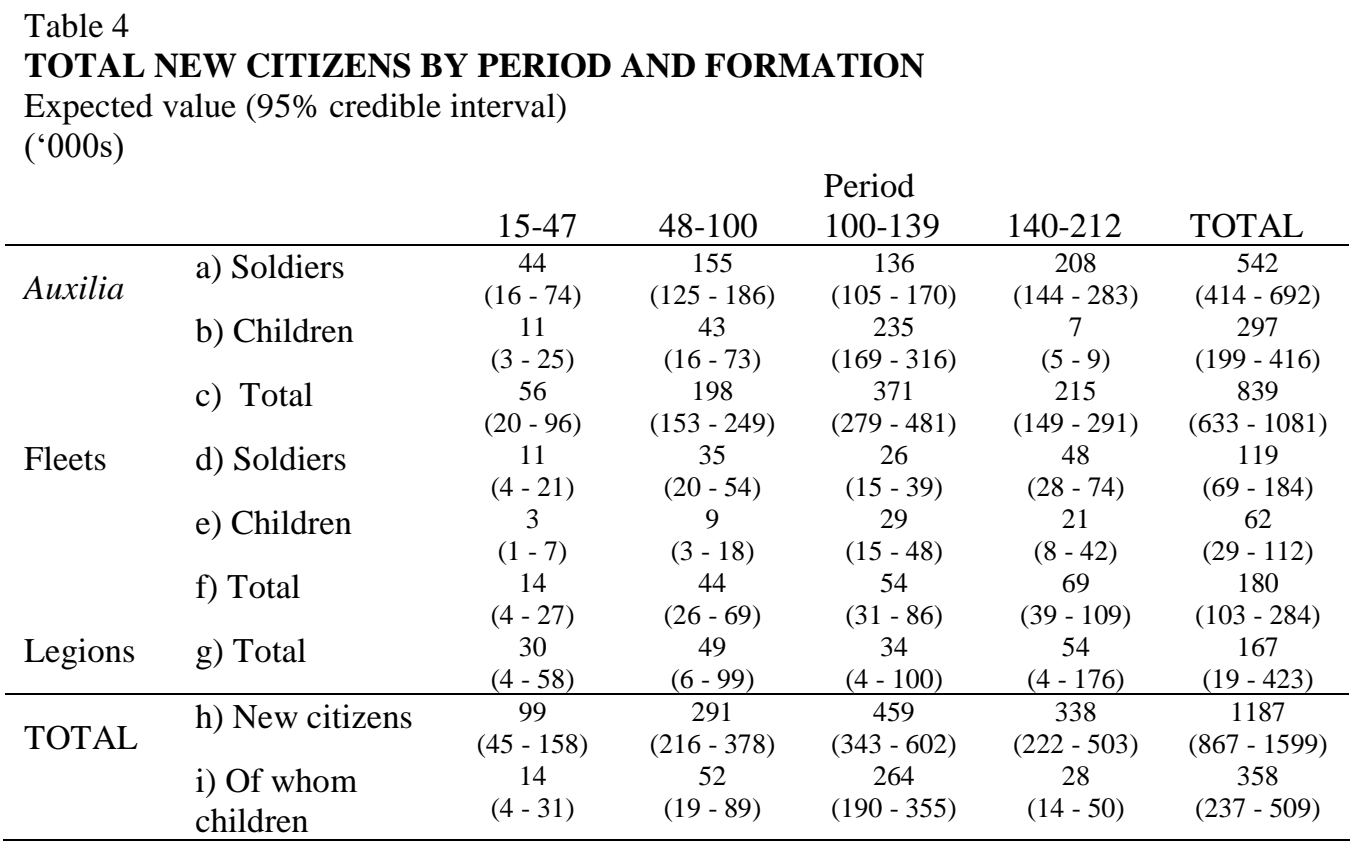




\section{Figure 1}

\section{GRANTS FOR CHILDREN OF CLASSICI IN JOINT AUXILIARY-FLEET CONSTITUTIONS AFTER $140 \mathrm{CE}$}

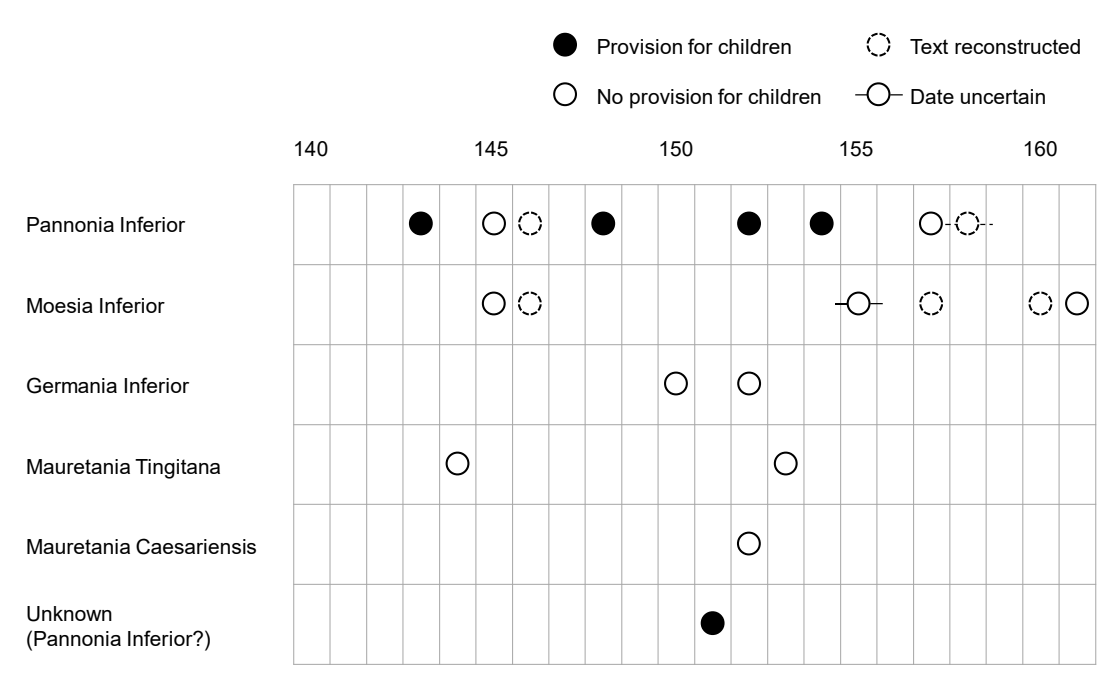

Note: Only includes joint auxiliary-fleet constitutions for which the relevant section of the text survives intact or can be reconstructed with confidence (indicated with dotted lines); excludes fleet-only constitutions

\section{Figure 2}

CHRONOLOGICAL DISTRIBUTION OF SURVIVING DIPLOMAS

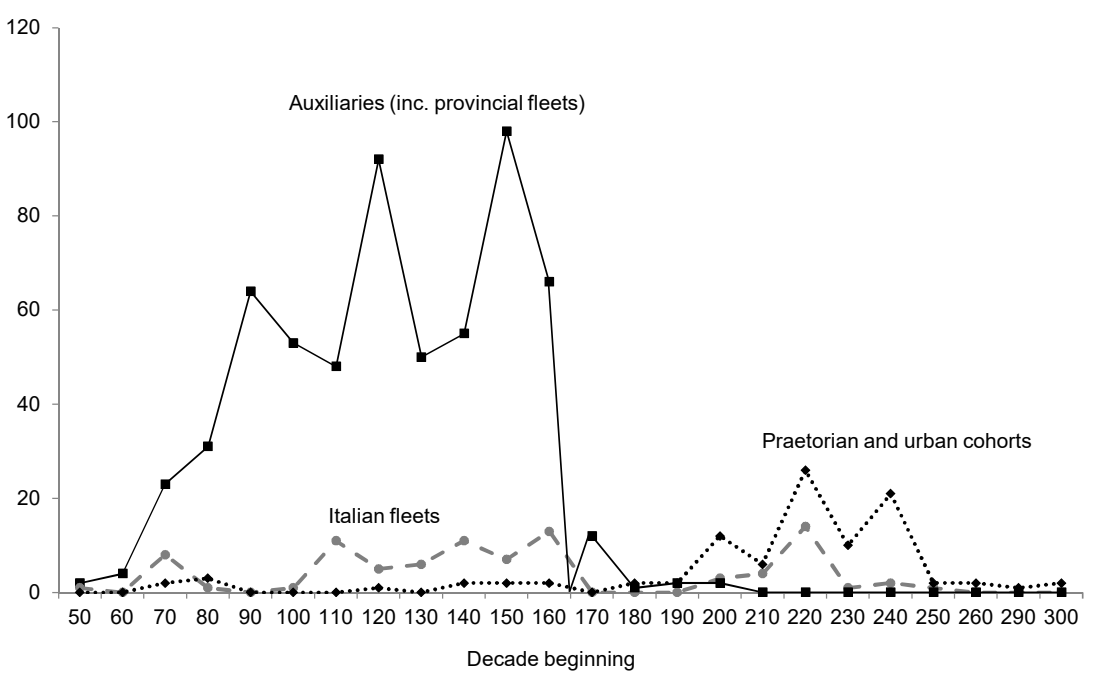

Note: Only includes diplomas that can be securely dated within a decade; excludes diplomas for the equites singulares Augusti 
Figure 3

NOMINAL STRENGTH OF THE AUXILIA, LEGIONS AND FLEETS

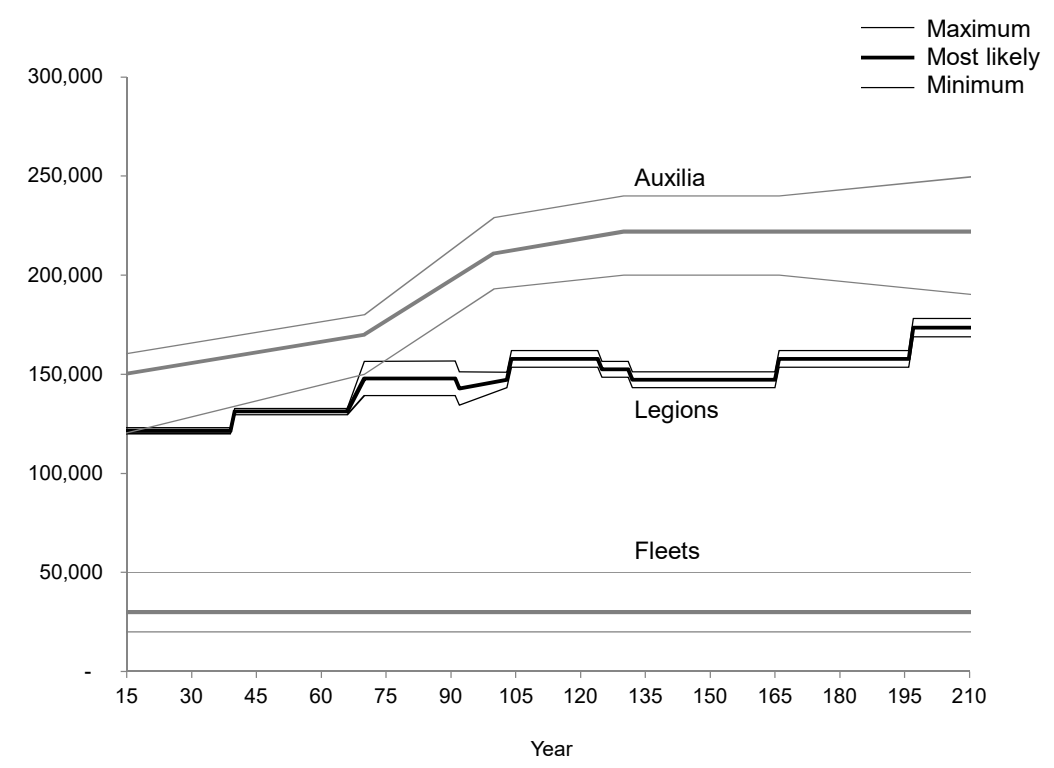

Figure 4

AVERAGE NUMBER OF CHILDREN NAMED

ON AUXILIARY DIPLOMAS

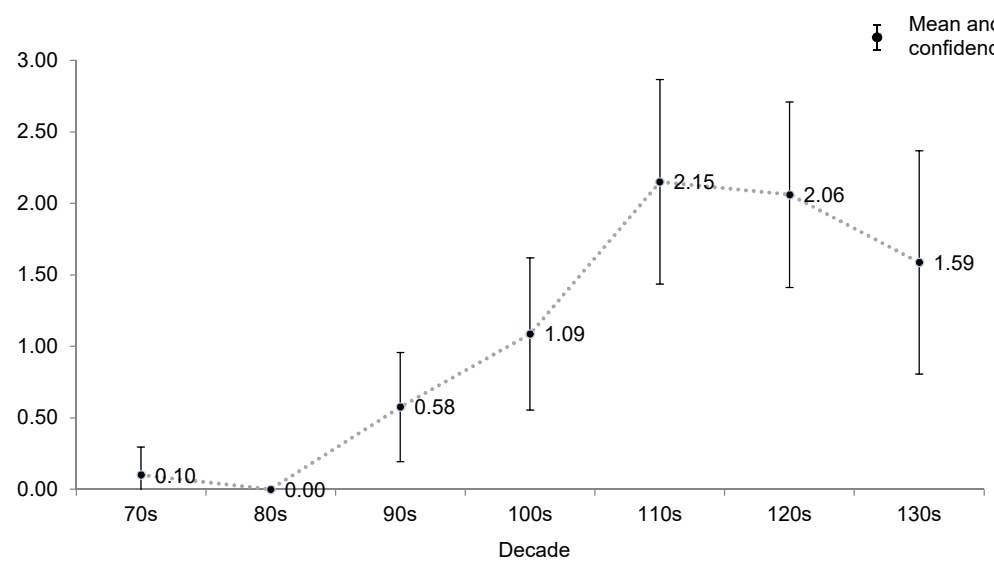

$\begin{array}{rccccccc}\mathrm{N}= & 10 & 20 & 33 & 29 & 20 & 41 & 23 \\ \begin{array}{r}\% \text { naming at } \\ \text { least 1 child }\end{array} & 10 \% & 0 \% & 27 \% & 45 \% & 80 \% & 59 \% & 52 \%\end{array}$




\section{Figure 5}

AVERAGE NUMBER OF CHILDREN NAMED

ON AUXILIARY AND ITALIAN FLEET DIPLOMAS

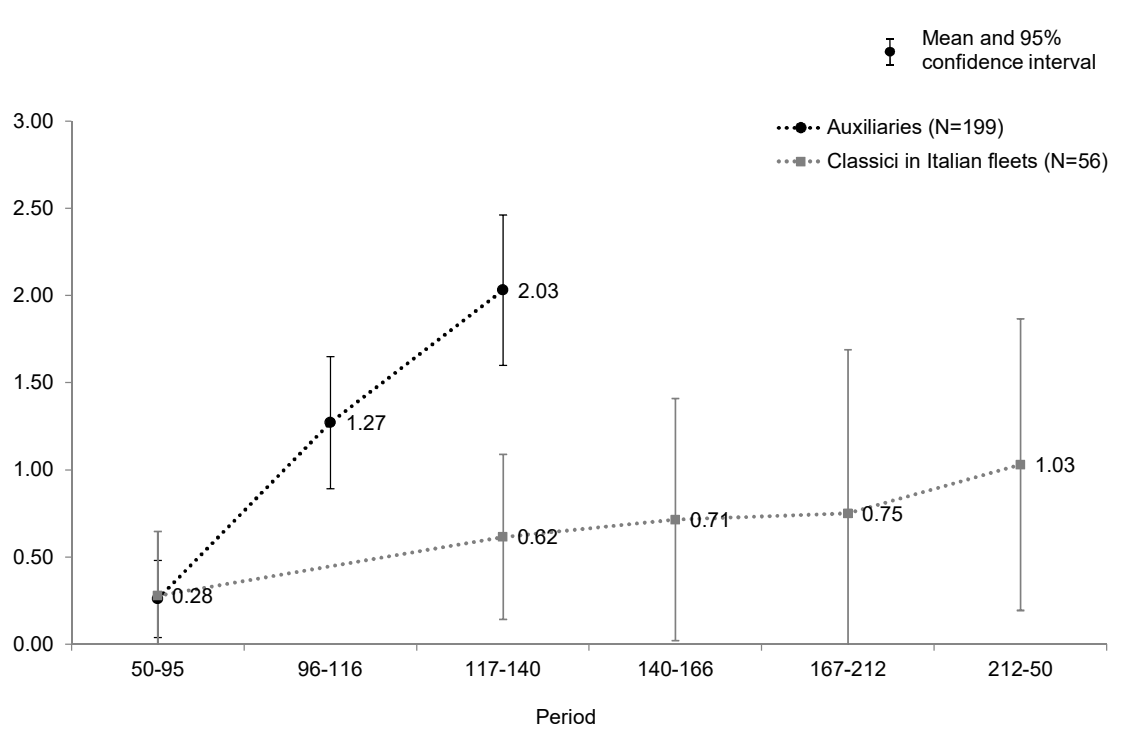

Figure 6

A MODEL OF RECRUITMENT, ATTRITION AND DISCHARGE

Soldiers per service cohort

Inputs

Outputs

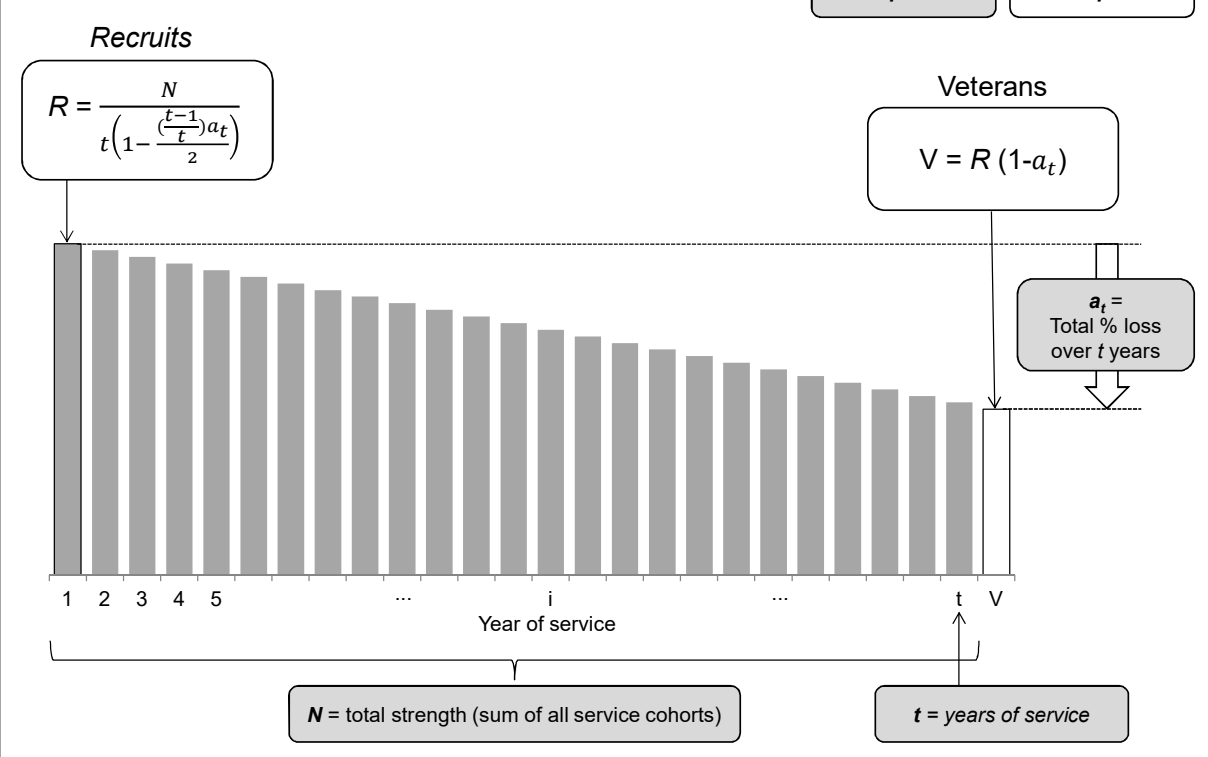

5 
Figure 7

PROBABILITY DENSITY FUNCTIONS

Probability

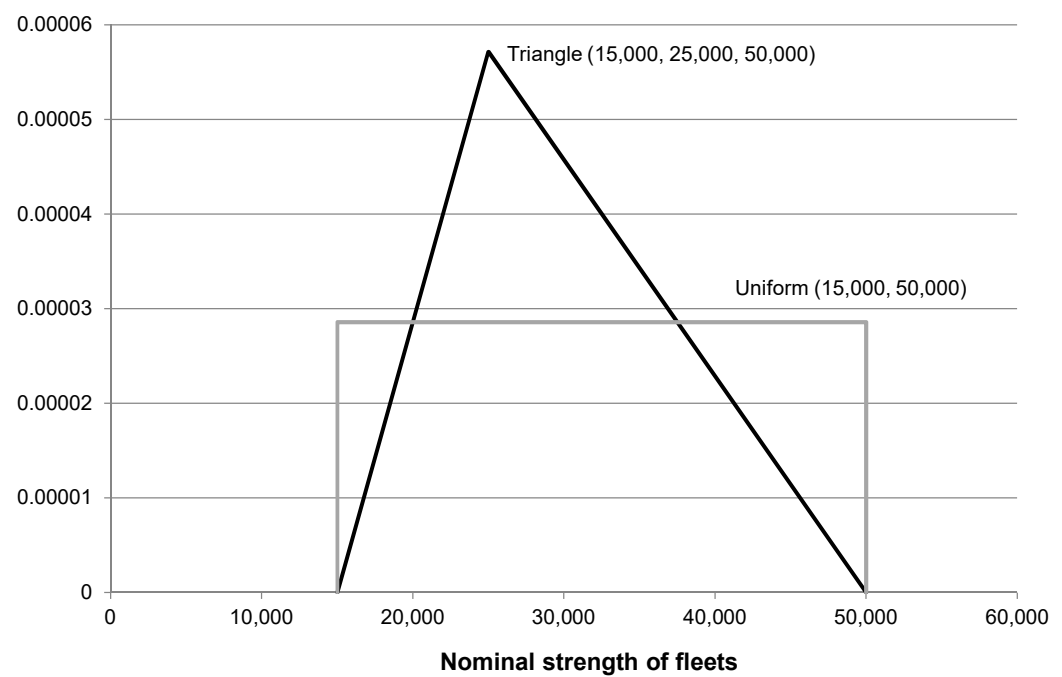

Figure 8

MONTE CARLO SIMULATION

Frequency of outcomes after $\mathbf{5 0 , 0 0 0}$ iterations

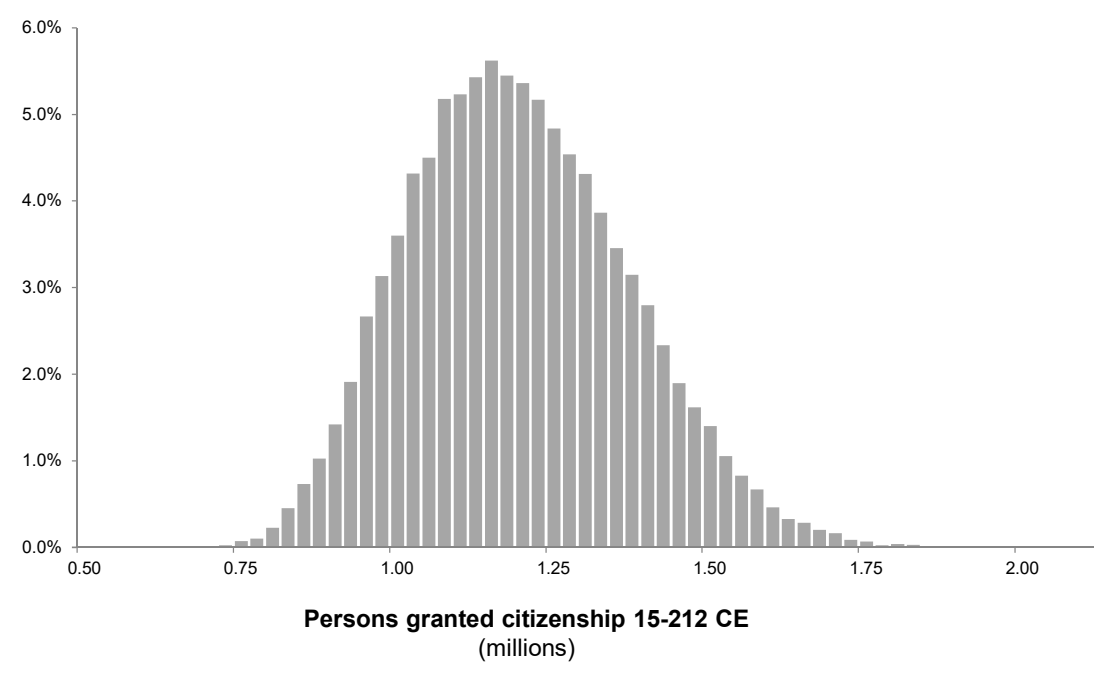




\section{Figure 9}

\section{NOMINAL RANGE SENSITIVITY}

Impact on output of varying each input variable from minimum to

maximum value while other variables are held constant

('000s of new citizens)

Citizens in auxilia 15-212 CE [4] \& displacement of peregrines from legions 15-212 CE [14]

$$
\text { Children/beneficiary }[6,10,11]
$$

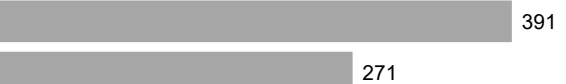

Peregrine recruitment to the legions in 15 CE [13]

Attrition rate [2]

Nominal strength of fleets [8]
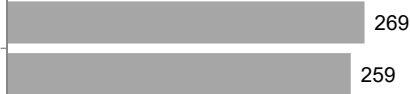

Actual/nominal strength [1]

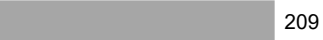

Nominal strength of auxilia [3]

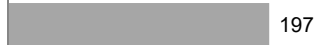

Scale of grants before Claudius [7]

Citizenship for children of legionaries? [15]

Term of service in auxilia [5]
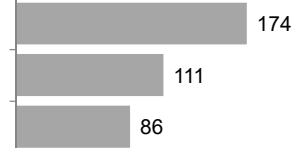

86

Grants to children for provincial fleets post 140 [9]

Nominal strength of a legion [12] 6 